Document downloaded from:

http://hdl.handle.net/10251/65762

This paper must be cited as:

Daraio, C.; Bonaccorsi, A.; Geuna, A.; Lepori, B.; Bach, L.; Bogetoft, P.; Cardoso, MF.... (2011). The European university landscape: A micro characterization based on evidence from the Aquameth project. Research Policy. 40(1):148-164.

doi:10.1016/j.respol.2010.10.009.

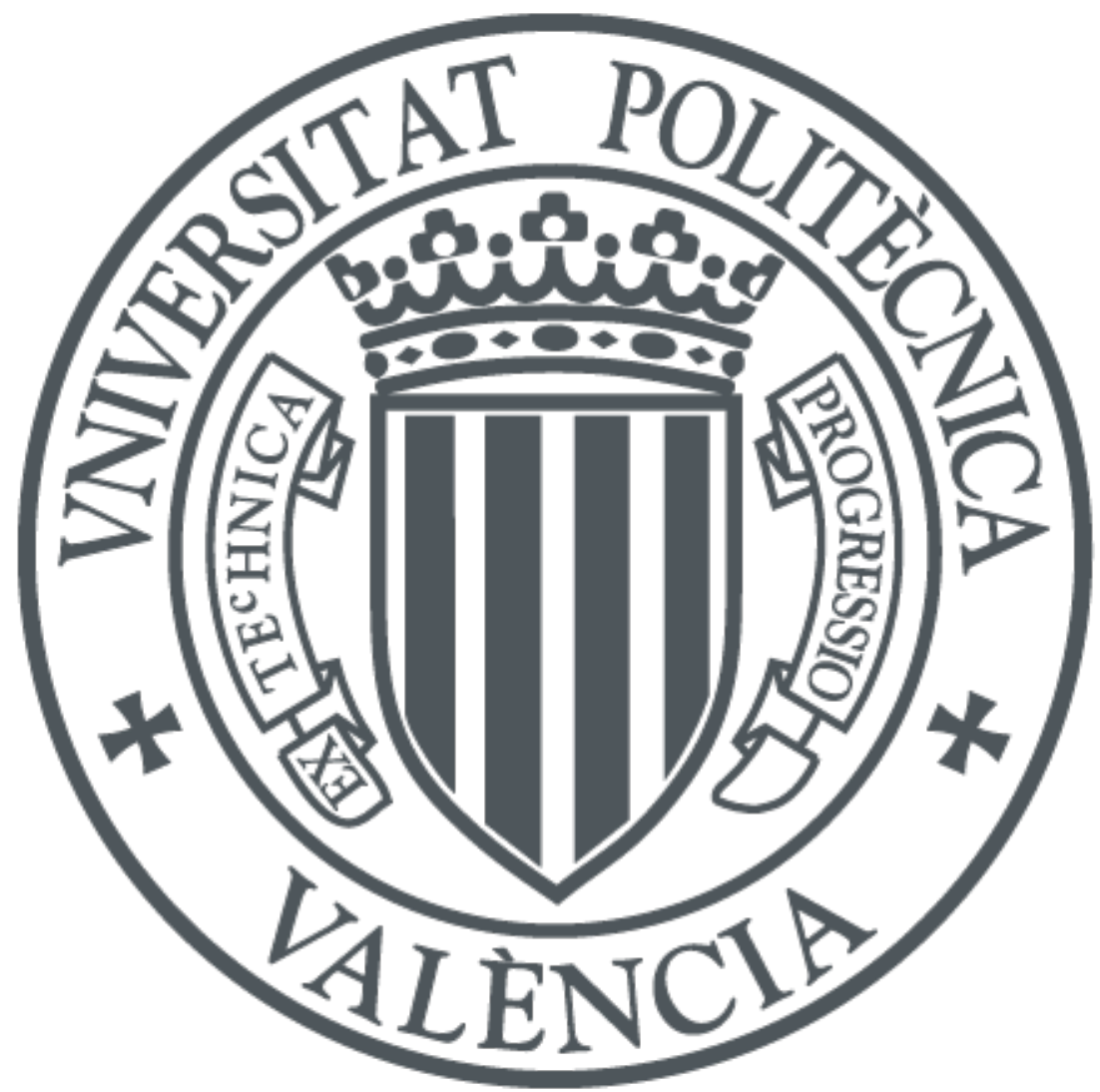

The final publication is available at

http://dx.doi.org/10.1016/j.respol.2010.10.009

Copyright Elsevier

Additional Information 


\title{
A micro characterization of the European university landscape: evidence from the Aquameth project
}

Cinzia Daraio $*^{1}$, Andrea Bonaccorsi*, Laurent Bach**, Peter Bogetoft***, Margarida F. Cardoso 3 , Elena Castro-Martinez ${ }^{\mp}$, Gustavo Crespi****, Ignacio Fernandez de Lucio $^{\mp}$, Harold Fried ${ }^{\psi}$, Adela Garcia-Aracil ${ }^{\top}$, Aldo Geuna ${ }^{\#}$, Annamaria Inzelt $^{\S}$, Ben Jongbloed^, Gerhard Kempkes ${ }^{ \pm}$, Benedetto Lepori ${ }^{\circ}$, Patrick Llerena**, Mireille Matt**, Maria Olivares ${ }^{l}$, Carsten Pohl ${ }^{\varepsilon}$, Tarmo Raty ${ }^{\mu}$, Maria J. Rosa ${ }^{9} 6$, Cláudia S. Sarrico $^{\complement}$, Léopold Simar ${ }^{\ominus}$, Stig Slipersaeter ${ }^{\mho}$, Pedro N. Teixeira ${ }^{\varphi}$, Philippe Vanden Eeckaut ${ }^{\omega}$

*Department of Electrical Systems and Automation, School of Engineering, University of Pisa, Italy.

** BETA, University of Strasbourg, France

*** Copenhagen Business School, Denmark

****International Development Research Centre (IDRC), Canada

${ }^{\circledR}$ INGENIO (CSIC-UPV), Spanish Council for Scientific Research, Spain

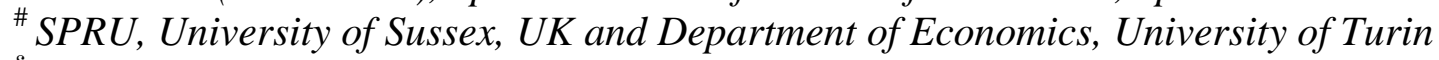

${ }^{\S}$ IKU, Financial Research Ltd, Hungary

$\wedge$ CHEPS, Netherlands

${ }^{ \pm}$Dresden University of Technology, Germany

- Università della Svizzera Italiana, Switzerland

${ }^{\mu}$ VATT, Finland

${ }^{\ominus}$ Institute of Statistics, UCL, Belgium

${ }^{\checkmark}$ NIFU-STEP, Norway

${ }^{\varphi}$ CIPES and Faculdade de Economia - U. Porto, Portugal

${ }^{\psi}$ Union College, Schenectady (NY), USA

${ }^{\omega}$ University of Lille, France

${ }^{3}$ CIIMAR and ICBAS - U. Porto, Portugal

${ }^{9}$ CIPES and Departamento de Economia, Gestão e Engenharia Industrial - Uni. Aveiro, Portugal

${ }^{6}$ CIPES and Secção Autónoma de Ciências Sociais, Jurídicas e Políticas - Uni. Aveiro, Portugal

${ }^{\Sigma}$ ifo Institute for Economic Research, Dresden, Germany

'University of Zurich

\begin{abstract}
This paper provides a new and systematic characterization of 488 universities (HEIs) coming from 11 European countries: Finland, France, Germany, Hungary, Italy, Netherlands, Norway, Portugal, Spain, Switzerland and UK. Using micro indicators built on the integrated Aquameth database, we characterize the European university landscape according to the following dimensions: history of foundation of universities, dynamics of growth, specialization patterns, subject mix, funding composition, differentiation of the offering profile and productivity.
\end{abstract}

Keywords: universities, size, growth, productivity, specialization, differentiation

\footnotetext{
1 Corresponding author. Address for correspondence: Cinzia Daraio, Department of Electrical Systems and Automation, University of Pisa, Via Diotisalvi, 2, I-56100 Pisa, Italy. Tel. +39 0502217 378; fax: +39 0502217333 ; e-mail: daraio@dsea.unipi.it
} 


\section{Introduction}

In the public debate there is an increasing recognition of the role of universities as strategic actors in knowledge creation and diffusion. At the same time, policy debates are largely based on country level statistics, country level scoreboards, and some international rankings of universities based on a few variables, often debatable. Scholars of higher education and Science and Technology (S\&T) policy systematically warn against the risks associated to aggregate data regarding highly heterogeneous and policy-dependent institutional systems. As a result, there is a widening gap between detailed qualitative and comparative studies and aggregate statistical analyses. This situation is unfortunate. In order to address these issues, we propose a quantitative approach to characterize the main features and functioning of European universities, based on internationally comparable microdata on individual units.

The paper is based on the exploitation of a new detailed database built under the EU project Aquameth (Advanced Quantitative methods for the Evaluation of the Performance of Public Sector Research) carried out under the network of Excellence PRIME ( $\left.6^{\text {th }} \mathrm{FP}\right)$. The Aquameth database, for the first time, integrates micro information available at the level of individual universities in 11 European countries on a census base, over the period 1994-2005. This means that all university institutions in all countries are covered, overcoming the intrinsic limitations of information based on samples on a highly heterogeneous population with small numbers. At the same time, microdata are based on administrative information extracted from various official sources at national level, usually not available to researchers. This information is not subject, as the official country level statistics produced by OECD or Eurostat, to a common definitional methodology, but must be made comparable ex post. This difficult task has been carried out through an extensive, expert-based work of examination of all administrative definitions and empirical evidence available, which the Aquameth team carried out in 2004-2007. After the completion of the project and the preparation of the current paper, two other counties showed interest to join the group (Sweden, Austria), demonstrating its potential interest.

This paper follows up and completes previous explorative analysis (see Bonaccorsi and Daraio, 2007a) carried out on a sub-sample of countries and variables, and focuses on the characterization of the European university system.

The paper unfolds as follows: Section 2 lays down the methodological framework followed for the construction of the integrated database; Section 3 presents the Aquameth database and discusses comparability issues, while Section 4 introduces the empirical evidence. Conclusions in Section 5 summarize the main results and call for a structural action at European level to carry out systematic integration and to build a coherent micro database on European Universities.

In the Appendix some detailed tables, the main sources of information by category of data, the structure of the Aquameth database, as well as the sources of funds by country are reported.

\section{Methodological framework}

\subsection{Unit of analysis}

First of all, the university institution is an appropriate level of analysis. Most of economics of research and innovation and of related policy making routinely uses national level aggregate data, in the tradition of Frascati and Oslo Manual. While these data are of large value for analysis and decision, they mask internal differences in national systems and loose important specificities. 
The fundamental reason for assuming the university as the unit of analysis is that at the university level the problem of attribution of inputs (in particular, human resources, funding, and physical capital) to specific units of output, can be kept under control.

Moving to lower levels of aggregation (e.g. departments) is a good strategy for evaluating research only, but makes the problem of joint output with teaching almost intractable in most disciplines. From the point of view of research it is even possible that a more relevant unit of analysis is the laboratory, not the department or institute (Knorr-Cetina 1995, Laredo and Mustar, 2001).

The allocation of inputs to specific types of outputs would require the specification of time budget allocation shares, but practical experience (for example in the bottom up process of production of statistics for OECD) shows that these data are far from reliable.

Moving to higher levels of aggregation, such as regional systems or national systems, emphasizes problems of comparability.

While other units of analysis are probably a better choice for analysis of research or higher education separately, universities are still the place where top level and budgetary decisions on recruitment of academic staff and allocation of funding are made.

Examining microdata on individual universities is therefore a legitimate methodological choice.

\subsection{Heterogeneity}

Of course, this level of analysis does not solve all problems. Universities themselves are collections of departments and schools, having large internal heterogeneity (Kyvik and Skovdin, 2003). In particular, there are several dimensions of heterogeneity that make the classification problem very hard:

- $\quad$ scope (generalist, specialist)

- $\quad$ subject mix (disciplines)

- coverage of educational activity (vocational training)

- coverage of research activity (Public Research Organizations -PROs)

- governance (public, private)

The first two dimensions refer to heterogeneity created by large internal differences across scientific and educational disciplines in cost structure, capital intensity, type of scientific output, number and type of publications. Specialist universities, usually found in applied disciplines (medical school, technical university, business school) cannot be compared with generalist universities, covering a large spectrum of disciplines. In turn, generalist universities exhibit large differences among themselves depending, for example, on the presence or absence of a medical school, or on the relative size of Human and Social Sciences. Although there is no systematic evidence, it can be said these differences are not dependent on country-level factors.

The issue of coverage is, on the contrary, largely dependent on the institutional tradition at country level. A large body of literature concerning higher education has concentrated on the general features of national higher education systems (Clark, 1983; Amaral, Jones and Karseth, 2002; Amaral, Meek and Larsen, 2003); this issue is particularly relevant in Europe, since the national and regional context of higher education are much more diverse than in the USA. Some countries allocate vocational training to separate higher education institutions, usually not allowed to grant $\mathrm{PhD}$ degrees, while other countries ask universities to cover all higher educational activities. Another country-level source of heterogeneity comes from the relative importance of PROs in performing research. In countries, such as France and, to a lesser extent, Germany, in which large part of research is performed in institutions external to universities, allocating outputs to production units may be problematic. In both cases unobserved heterogeneity may lead to wrong allocation of inputs and outputs. This diversity requires multi-layer empirical analysis and careful comparative discussion. 
Finally, the issue of governance is a general one, but it takes significantly different meanings in different countries. Private universities are comparatively more important in Latin countries (Spain, Portugal, to a lesser extent Italy) and in Eastern European countries. In some cases they cover unfilled educational needs, particularly after transition in East Europe. The level of quality is extremely variable, from top level and research-oriented universities (e.g. for Italy San Raffaele in medical research or Bocconi University in economics) to poor level degree producers in weakly regulated markets.

The issue of heterogeneity is a serious one, which has attracted the attention of the Aquameth project since the beginning. The approach followed has been one of disentangling separately each source of heterogeneity, examining available indicators, and making explicit various schemes for classification or for inclusion of dummy variables.

For many of the mentioned problems a reasonable solution has been found (see Section 3.1). If not, we recognize the problem and leave room for further research.

\subsection{Input-output characterization}

Another methodological choice done in the Aquameth project is to accept a representation of universities as production units, able to transform vectors of inputs into vectors of outputs. Any effort to build comparable indicators of university structure and activity, however, is problematic. Considered as a production activity, university production is intrinsically multidimensional, based on a multi-input, multi-output relation, in which, differently from standard production activity, both inputs and outputs are not only qualitatively heterogeneous but sometimes truly incommensurable, the relation between inputs and outputs is not deterministic, the output is lagged but with a non fixed lag structure, and the relative weight of different types of output is subject to considerable debate and political appreciation (Bonaccorsi and Daraio, 2004).

In particular, there is no universally accepted theory or methodology to define a system of weights able to capture the relative importance of research, teaching (both undergraduate and postgraduate), patenting, university-industry collaboration, public policy activities, and other types of output. Given that these different outputs do not have market prices, it is difficult to build an aggregate measure of performance and to discuss economic implications, in terms, for example, of strategic advantage or resource allocation. These features are crucial to a largely public system, such as the higher education system in most European countries.

These conceptual issues are magnified by the well known problem of "data constraint": some of the most important problems in the economics and policy of science and higher education cannot be addressed empirically due to lack of data or poor quality of data or to conceptual problems in defining and measuring suitable indicators (Griliches, 1994; Mairesse and Griliches, 1998).

Within a production framework, we need an approach that directly addresses the issue of complementarities. The theory of complementarity is one of the least developed in economics, and many standard problems are addressed in terms of simple marginal rates of substitution, ignoring nonlinearities and external influences. In fact, the econometrics of complementarity in the higher education and research fields is heavily underdeveloped (Marsh, 2004 and Ehrenberg, 2004).

Some of the most intriguing problems in these fields, however, require exactly an estimation of complementarity or substitution effects. Examples can be found in the complex trade-offs between research and teaching, between undergraduate and postgraduate teaching, between publication and patenting, between research and third mission activities: here the substitution vs complementarity effects may not be stable across the whole distribution (for early econometric evidence see Cohn, Rhine and Santos (1989); or De Groot, McMahon and Volkwein, 1991). Other remarkable cases of positive complementarities we may want to examine include the problem of academic vs 
nonacademic staff, of the composition of academic staff by seniority (professor, associate professor, assistant professor or similar level), of the complementarity between human capital and physical infrastructure (recent evidences based on a sub-sample of six European countries included in the Aquameth database can be found in Bonaccorsi, Daraio and Simar, 2007).

\subsection{Relevance for the policy debate}

Universities are an invention of European civilization. In the modern era, their mission has been crystallized in the systematic combination of education and research, subsequently imitated by younger American universities. European universities have been hugely successful until the end of $\mathrm{XX}$ century in giving good quality education to young generations and in producing state of the art scientific research.

It is largely recognized that this leadership has been lost in the last part of XX century. The successive waves of increase in participation rates of young cohorts and massification; the pressure for new types of education in the knowledge society (professional upgrading, long life learning); the demand for diversification of the spectrum of research activity including applied and contract research; the increased international competition in pure research; the new roles assigned to universities in technology transfer, industry collaboration, direct interaction with society, management of IPR: all these elements have placed universities in European countries under severe stress.

This situation is at the core of an animated policy debate in Europe. We contribute to this debate by offering a robust empirical base.

This paper offers a first introduction to descriptive aspects of European universities. The overall research agenda of Aquameth, however, includes a number of quantitative exercises on policyrelated issues, some of which already in the publication stage.

In fact, the construction of a European platform of microdata on universities allowed to address a number of highly relevant policy issues such as economies of scale and scope in academic production, trade-off research vs. teaching; trade-off publications vs. applied industry research; complementarity effects in inputs; structural vs project funding; public vs private funding; impact of national differences in European systems of Higher Education and research; impact of regional differences.

\section{The Aquameth database}

The main purpose of the Aquameth project (Advanced quantitative methods for the evaluation of the performance of public research systems), set up under the European Network of Excellence PRIME (Policies for Research and Innovation in the Move towards the European research area), was to develop a quantitative micro-based approach to the analysis of universities, by taking individual universities as units of observation. Data should not be primary data collected at universities, but secondary data, available at Ministry level or other institutional level in each country, and not published and/or not made comparable across countries. The project wanted to explore the availability, accessibility and comparability of existing data, and the feasibility of an integrated dataset at European level. Countries were selected with the simple criteria of having secondary data available and accessible by researchers. In the first round, Aquameth 1, on which Bonaccorsi and Daraio (2007a) is based on, six countries were selected: Italy, Norway, Portugal, 
Spain, Switzerland, United Kingdom. A second project, Aquameth 2 extends to France, Hungary and Netherlands. Finally, a consolidated step included Germany and Finland and completes the data available for also other countries. The evidence reported in this paper is based on the final and updated database built on all the 11 countries.

The approach followed sharply differs from those followed by main international organizations, governments, and policy analysts, that use statistics at country level, aggregated according to the Frascati and Oslo Manual. In aggregate statistics you observe only one moment of the distribution (average value) and totally ignore other moments of the distribution and associated indicators, such as range, variance, coefficient of variation or skewness. This is important because almost all variables of interest for policy making do not have a normal distribution. For example, scientific productivity of researchers is known to have an highly-skewed distribution, due to cumulative factors, path dependency, and self-selection.

The construction of a dataset for analysis at the microlevel is a risky and frightening exercise. There is no standardization of definitions and statistical units. Institutional differences are so large that the same word means totally different things in different countries. National policies have profound effects on the university system, so that the research design should incorporate a regular update of legislative and administrative changes.

The Aquameth project addressed this issue by developing a multi-method approach.

First, each country in the initial project has been covered by an extensive case study, pointing out to recent changes in policies and main trends. National case studies allow to take into consideration the heterogeneity of institutional frameworks, and also the ever changing impact of policies. Second, comparative analysis has carefully carried out highlighting data comparability problems and possible solutions (Bonaccorsi, Daraio, Lepori, Slipersaeter, 2007) Finally, in the cases in which the comparability of data was demonstrated, they were integrated in the dataset. This is a major step in the economics and political science of higher education, since most existing literature is based either on national datasets or on comparative analysis. It is the first example, to our knowledge, of construction of a large dataset on European universities having as unit of analysis the census of universities in 11 country, covering 488 institutions.

The main categories of variables in the Aquameth database were organized in the following broad areas: General information on the HEI; Revenues; Expenditures; Personnel; Education production; Research and technology production. Table 1 below presents the detailed list of the variables whilst Table 2 shows the number of universities in the database by country. 


\begin{tabular}{|c|c|}
\hline Area & categories \\
\hline General information & $\begin{array}{ll}\text { - } & \text { Year of foundation } \\
\text { - } & \text { Region (NUTS) } \\
\text { - } & \text { Type (university, technical college etc) } \\
\text { - } & \text { Governance (public, private) } \\
\text { - } & \text { University hospital (dummy) } \\
\text { - } & \text { Specialization } \\
\text { - } & \text { Number of fields covered }\end{array}$ \\
\hline Revenues & $\begin{array}{ll}\text { - } & \text { Total revenues of the university } \\
\text { - } & \text { Tuition and fees } \\
\text { - } & \text { Government appropriations } \\
\text { - } & \text { EU and other international funding } \\
\text { - } & \text { Private funding (profit and non-profit) } \\
\text { - } & \text { Asset revenues } \\
\text { - } & \text { Other revenues. }\end{array}$ \\
\hline Expenditures & $\begin{array}{l}\text { - } \text { Total expenditures } \\
\text { - } \text { Personnel expenditures, if possible divided between personnel } \\
\text { categories } \\
\text { - } \quad \text { Current expenditures } \\
\text { - } \quad \text { Capital expenditures } \\
\text { - } \quad \text { Other expenditures }\end{array}$ \\
\hline Personnel & $\begin{array}{ll}\text { - } & \text { Total academic staff (Headcount or FTE) } \\
\text { - } & \text { Full professors } \\
\text { - } & \text { Associate professors } \\
\text { - } & \text { Researchers } \\
\text { - } & \text { Other academic staff } \\
\text { - } & \text { Technical and administrative staff }\end{array}$ \\
\hline Education production & $\begin{array}{ll}\text { - } & \text { Number of enrolled students } \\
\text { - } & \text { Number of foreign students } \\
\text { - } & \text { Number of graduates (when applicable divided in long cycle and } \\
\text { - } & \text { Nhort cycle graduates) } \\
\text { - } & \text { Number of PhD students } \\
\text { - } & \text { Number of master students } \\
\text { - } & \text { Number of master degrees }\end{array}$ \\
\hline Research and technology production & $\begin{array}{ll}\text { - } & \text { ISI publications } \\
\text { - } & \text { Patents } \\
\text { - } & \text { Spin-off companies } \\
\text { - } & \text { R\&D revenues } \\
\text { - } & \text { R\&D expenditures }\end{array}$ \\
\hline
\end{tabular}

Table 1. Main categories in the Aquameth database 


\begin{tabular}{|lcc}
\hline Country & $\begin{array}{c}\text { No. of } \\
\text { universities }\end{array}$ & Period \\
\hline \hline CH & 12 & $1994-2003$ \\
DE & 72 & $1998-2003$ \\
ES & 48 & $1994-2004$ \\
FI & 20 & $1994-2006$ \\
FR & 88 & $1994-2006$ \\
HU & 16 & $2001-2004$ \\
IT & 79 & $1995-2005$ \\
NL & 13 & $1994-2004$ \\
NO & 10 & $1995-2003$ \\
PT & 14 & $1997-2002$ \\
UK & 116 & $1996-2003$ \\
\hline
\end{tabular}

Table 2 Number of universities in the Aquameth database (488) by country.

Table 3 and 4 illustrate the time series coverage by country and the data available by research area respectively.

The overall dataset has also been organized in four fields, namely Natural Sciences, Medicine, Engineering and Technical Sciences, Human and Social Sciences. The fields have been constructed by building a concordance matrix between classes of ISI publications, used to represent the research output, and classes of academic disciplines as standardized by OECD, used to represent the teaching activity. Therefore our fields do not represent individual departments or schools, bur rather relatively homogeneous collections of inputs (academic staff) producing both teaching ad research in the same area of output. Controversial assignments have been extensively discussed during the project, reaching substantial consensus. Details of the procedure are available from the corresponding author at request.

\begin{tabular}{|c|c|c|c|c|c|c|c|c|c|c|c|c|c|}
\hline Country & 94 & 95 & 96 & 97 & 98 & 99 & 00 & 01 & 02 & 03 & 04 & 05 & 06 \\
\hline Finland & $\mathrm{x}$ & $\mathrm{x}$ & $\mathrm{x}$ & $\mathrm{x}$ & $\mathrm{x}$ & $\mathrm{x}$ & $\mathrm{x}$ & $\mathrm{x}$ & $\mathrm{X}$ & $x$ & $\mathrm{x}$ & $X$ & $*$ \\
\hline France & & $*$ & * & $*$ & $*$ & $\mathrm{x}$ & $\mathrm{x}$ & $\mathrm{x}$ & $\mathrm{x}$ & $\mathrm{x}$ & * & $*$ & * \\
\hline Germany & & & & & $\mathrm{x}$ & $\mathrm{x}$ & $\mathrm{x}$ & $\mathrm{x}$ & $\mathrm{x}$ & $\mathrm{x}$ & & & \\
\hline Hungary & & & & & & & & $\mathrm{x}$ & $\mathrm{x}$ & $\mathrm{x}$ & $\mathrm{x}$ & & \\
\hline Italy & & $*$ & $\mathrm{x}$ & $\mathrm{x}$ & $\mathrm{x}$ & $\mathrm{x}$ & $\mathrm{x}$ & $\mathrm{x}$ & $\mathrm{x}$ & $\mathrm{x}$ & $\mathrm{x}$ & $*$ & \\
\hline Netherland & $\mathrm{x}$ & $\mathrm{x}$ & $\mathrm{x}$ & $\mathrm{x}$ & $\mathrm{x}$ & $\mathrm{x}$ & $\mathrm{x}$ & $\mathrm{x}$ & $\mathrm{x}$ & $\mathrm{x}$ & $\mathrm{x}$ & & \\
\hline Norway & & $\mathrm{x}$ & $\mathrm{x}$ & $\mathrm{X}$ & $\mathrm{x}$ & $\mathrm{x}$ & $\mathrm{x}$ & $\mathrm{x}$ & $\mathrm{x}$ & $\mathrm{x}$ & & & \\
\hline Portugal & & & & $\mathrm{x}$ & $\mathrm{x}$ & $\mathrm{x}$ & $\mathrm{x}$ & $\mathrm{x}$ & $*$ & & & & \\
\hline Spain & $\mathrm{x}$ & $\mathrm{x}$ & $\mathrm{x}$ & $\mathrm{x}$ & $\mathrm{x}$ & $\mathrm{x}$ & $\mathrm{x}$ & $\mathrm{x}$ & $\mathrm{x}$ & $\mathrm{x}$ & $\mathrm{x}$ & & \\
\hline Switzerland & $*$ & $\mathrm{x}$ & $\mathrm{x}$ & $\mathrm{x}$ & $\mathrm{x}$ & $\mathrm{x}$ & $\mathrm{x}$ & $\mathrm{x}$ & $\mathrm{x}$ & & & & \\
\hline United Kingdom & $*$ & $*$ & $\mathrm{x}$ & $\mathrm{x}$ & $\mathrm{x}$ & $\mathrm{x}$ & $\mathrm{x}$ & $\mathrm{x}$ & $\mathrm{x}$ & $\mathrm{x}$ & * & $*$ & \\
\hline
\end{tabular}

Table 3. Aquameth database: time series coverage of the data by country. Legend: $\mathrm{x}=$ full coverage; ${ }^{*}=$ some variables are missing. 


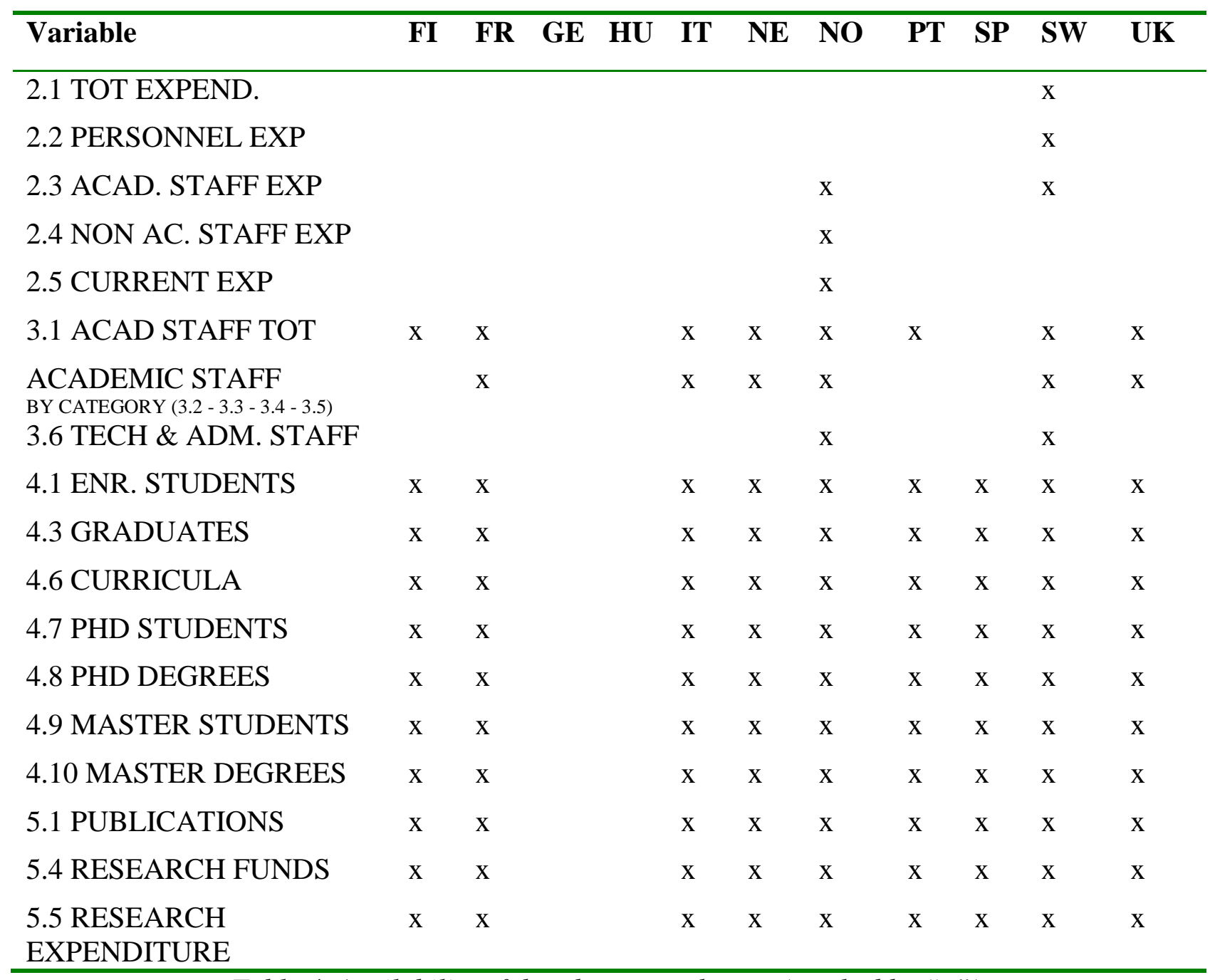

Table 4. Availability of data by research area (marked by “ $\mathrm{x}$ ”).

\subsection{The comparability issue: problems and possible solutions}

The next step was to examine the cross-country comparability of data, as discussed at length in Bonaccorsi, Daraio, Lepori and Sliperstaeter (2007). It turned out that for some variables international comparability was methodologically acceptable, while for others there was no way to carry out such a comparison. Three main categories of comparability problems arise.

First, there are differences in the organization and governance structure of national HE systems. European systems largely differ in terms of comprehensiveness: unitary systems include vocational training in the university (as in Italy) while dual systems have a separate track (as in Germany). Furthermore, in countries such as Spain, Portugal or Italy there is a significant, although minor, role of private universities, that are almost absent in other countries. In addition, the constitutional architecture assigns the responsibility for universities to the national government in most countries, or to regional or state governments in federal countries such as Spain or Germany (see on these issues Huisman and Kaiser, 2001; Kyvik and Skovdin, 2003; Kyvik, 2004). Separate analyses by groups of homogeneous countries are mandatory here, at least for those variables mostly dependent on these features. Alternatively, normalization of variables around the national average have been experimented. 
Second, individual universities are heterogeneous with respect to the subject mix. This may introduce large distortions, because cost per students and other indicators largely differ across disciplines (Filippini and Lepori, 2007). In the Aquameth project two solutions were tested. Across all countries a distinction has been operationalized between generalist universities and specialist ones, and quantitative analyses have been carried out separately. As an alternative, for some countries data on disciplinary area were available, and a categorization in four areas was adopted (Human and Social Sciences, Engineering and Technical Sciences, Natural Sciences and Medicine), connecting data on academic staff and publications to data on students. Universities associated to hospitals were identified with a dummy.

Third, administrative definitions may differ in irreducible way. As an example, the definition of private funding to universities in Portugal includes also contract research, while in other countries they are separated. There is no way to get around this problem. The only solution was the construction of new indicators as the normalization of individual universities around the country average.

Finally, there is no alternative to examining in depth the qualitative characteristics of national institutional contexts, in order to give a robust meaning to any proposed indicator. Taking into account all these issues, we can describe our proposed characterization of the European universities in the next section.

\section{Positioning universities in the European landscape}

Bonaccorsi and Daraio (2007b) propose that universities have emergent strategies (rather than deliberate: Mintzberg, 1979), that can be defined and (possibly) measured as positioning in the multidimensional output space.

Here we develop further the approach to characterize universities from a strategic point of view, using quantitative indicators (Bonaccorsi and Daraio, 2008). More precisely, we are looking for elements that may contribute to the notion of structural differentiation of universities, or strategic profile. In order to address the problem from a quantitative point of view, we define the strategic profile of universities with respect to the vectors of resources used (inputs) to produce teaching, research an third mission (outputs). Taking into account the constraints in the structure of funding and educational demand, we are interested in understanding whether universities follow consistent patterns of structural evolution and differentiation driven by purposeful behaviour, or rather are completely determined by external factors.

We combine measures related to inputs (funding), measures related to outputs and configuration of outputs (publications, $\mathrm{PhD}$, educational offering profile) and measures of dynamic performance (rate of growth in enrolments). We also characterize the institutional process of creation of new universities over time.

\subsection{The dynamics of the creation of universities in Europe}

The process of creation of new universities is subject to a variety of historical factors and apparently there are no strong regularities. The kernel distribution of the age of universities (Figure 1) shows two peaks, one around 100 years, the other, much smaller, at 500 years. 


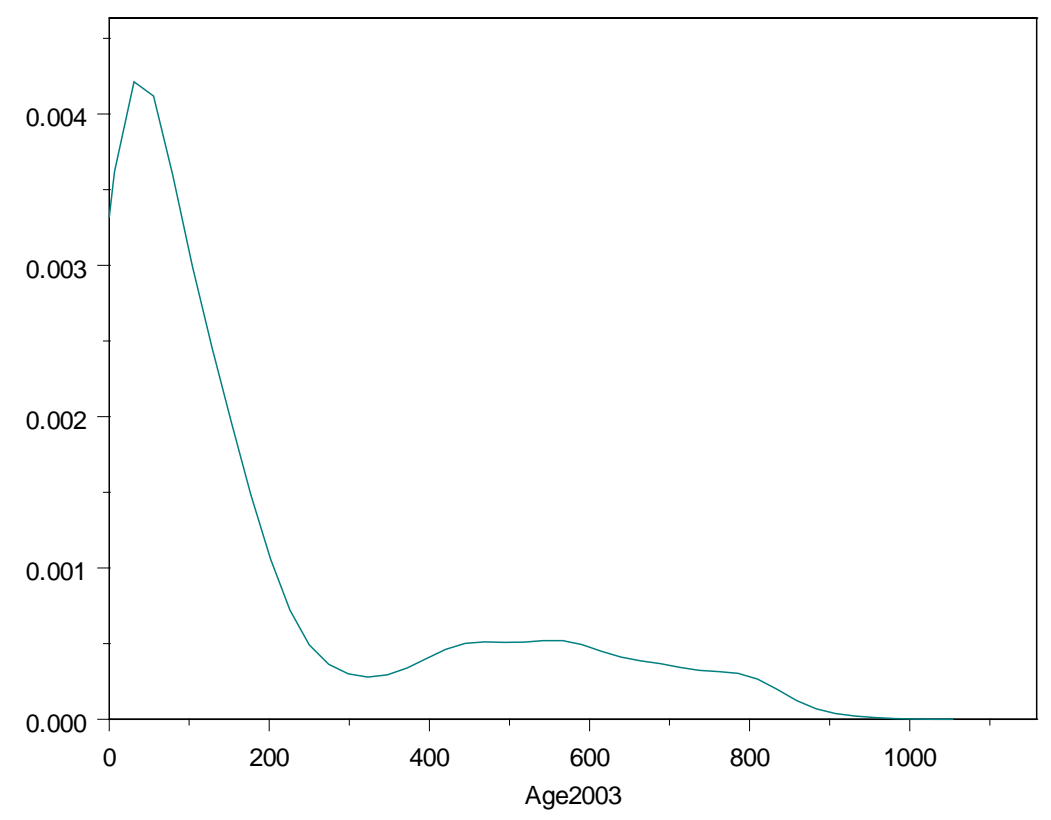

Figure 1 Kernel distribution of European universities' age (Aquameth sample, 11 countries, $n=$ 488)

To understand how this age structure originated, let us inspect the distribution over time.

The cumulate distribution shows a linear growth since Middle Age up to the end of XVIII century, and then an exponential growth starting in the XIX century (Figure 2). The cumulate distribution in the XX century, on the other hand, shows a further acceleration after 1970 (Figure 3). The most recent dynamics seems to follow the waves of entry into higher education of large populations of young people, immediately after Second World War, in the '60s and '70s, and after the '90s.

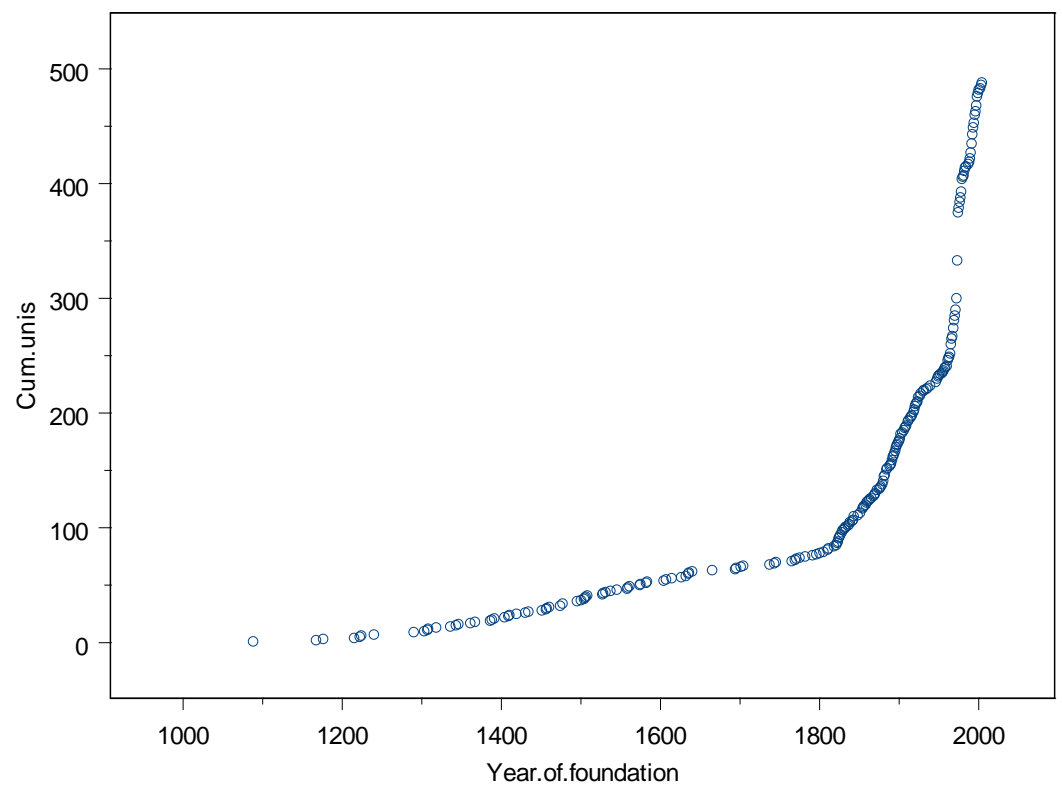

Figure 2 Cumulate number of universities by year of foundation 


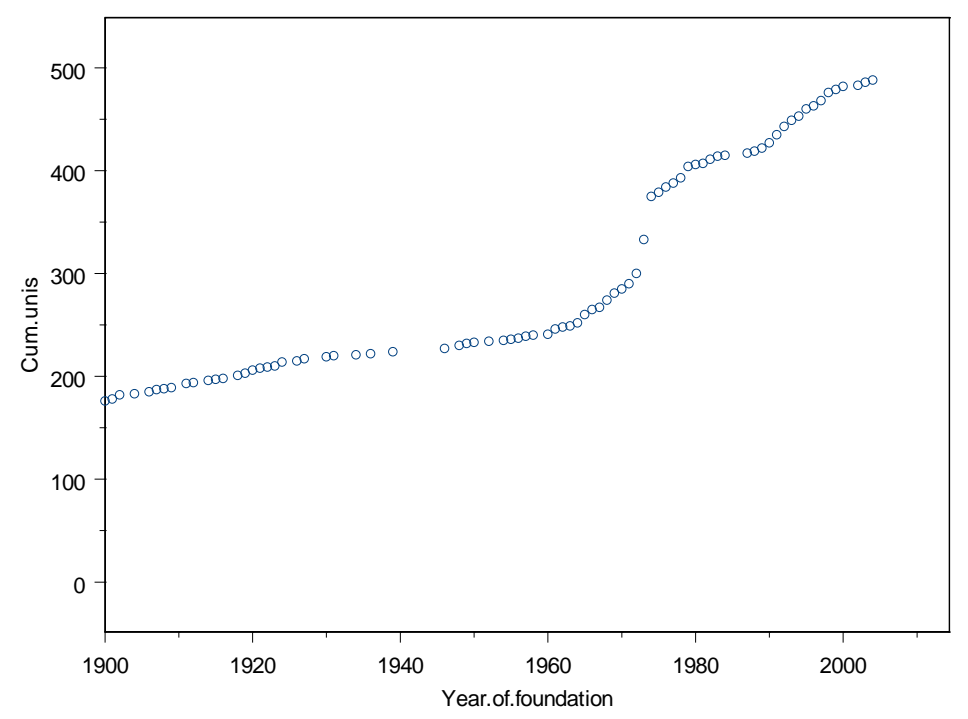

Figure 3 Cumulate number of universities by year of foundation. 1900-2000

Looking at national differences in the history of university creation (Figure 4), several patterns emerge. Large European countries, with the exception of Spain, reach a considerable number of universities in the Renaissance period. Italy and France are historically the place of birth of the university institution. France dominates in terms of number of universities established until 1800. Starting from 1800, the United Kingdom shows an impressive process of establishment of new universities, some of which were initially created as Polytechnics and subsequently recognized as universities. All large countries, including Spain but with the interesting exception of UK, exhibit a sharp increase in the number of universities starting in 1970. The historical dynamics sheds light on an important institutional difference. Faced with the second wave of mass higher education in the '60s and '70s, the UK government did not create new universities similar to existing ones, but rather gave the recognition of university to old Polytechnics, enlarging the educational supply without congesting research universities. Polytechnics were invited to invest into research (more of the applied type), while keeping the traditional educational mission at the core. In this way a strong effect of internal differentiation was originated. 


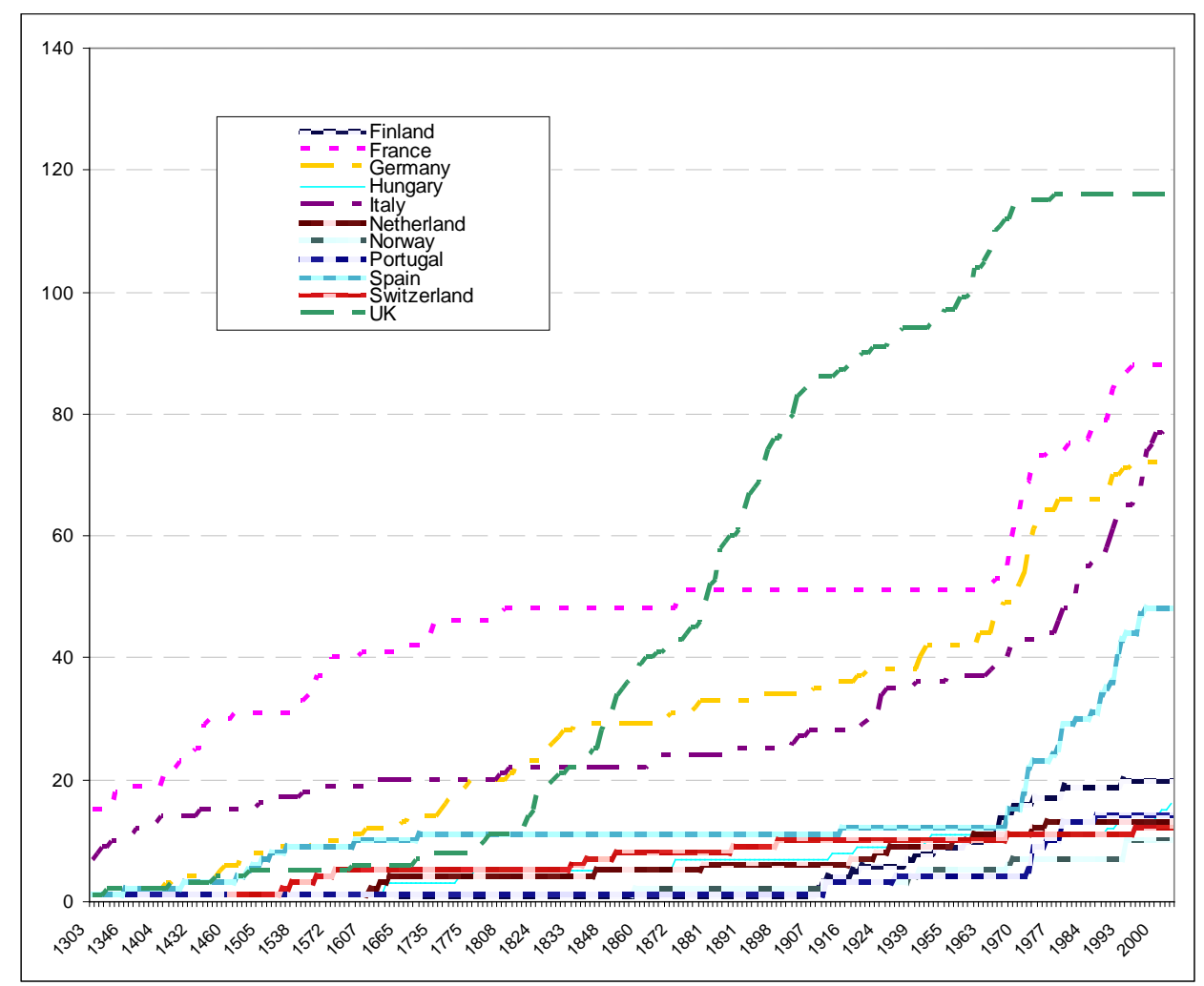

Figure 4 Cumulate number of universities by year of foundation by country

A similar dynamics seems to emerge in small countries, although some "outlying” very old universities are only found in Portugal and Hungary as Figure 5 shows along with the distribution of universities' age by country. In the case of Hungary, the whole higher education system developed in a disconnected way because of the turbulent history of the country.

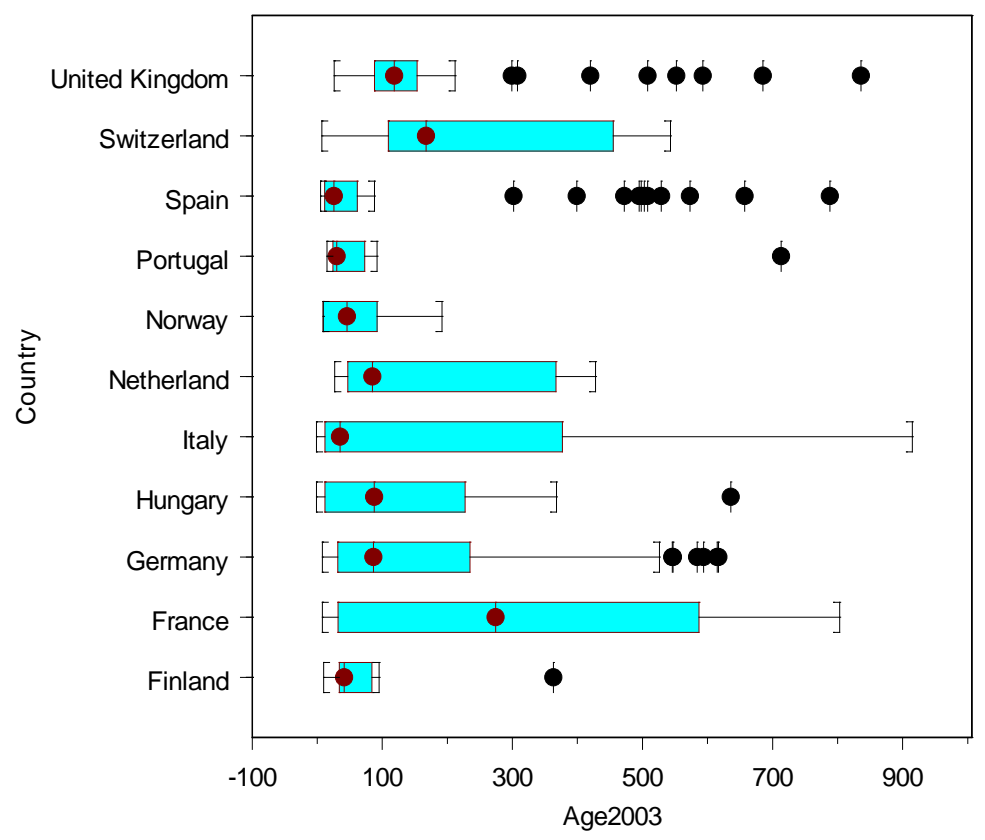

Figure 5 Boxplots of universities' age by country. 
As a result, Figure 5 shows the following patterns: (a) Italy and France have the eldest institutions and $75 \%$ of universities are distributed on a large support; (b) United Kingdom, Spain and Portugal have less very old universities, many of which are outliers; (c) countries of German culture (Germany, Netherlands, Switzerland) and, to a lesser extent, Hungary, had few universities in Medieval age that could continue their activities after a couple of centuries break, so their median age is relatively low; (d) Norway and Finland have very young universities.

In general, the distributions are highly skewed, as it emerges from visual inspection of the boxplots. In the literature on population ecology, the time path of foundation of organizations is considered an important object of analysis (Hannan and Freeman, 1977; 1989; Baum, 1996). Creation rates and exit rates are predicted on the basis of age, density and size of organizations in the population (Hannan and Freeman, 1984; Bruderl and Schussler, 1990; Henderson, 1999). It remains to be investigated whether similar regularities hold for universities, whose institutional status does not include, de facto, the possibility of death. We believe the industrial organization of universities, including creation, survival and growth (perhaps not exit) is a promising research area.

\subsection{Size distribution, concentration and growth}

Universities are unevenly distributed with respect to size, as measured by both students and academic staff. Figure 6 shows an extremely thin long tail on the right of the distribution, while almost all of the density is located below 50,000 students.

\begin{tabular}{lcccccc}
\hline Country & Min & $\begin{array}{c}\text { First } \\
\text { quartile }\end{array}$ & Mean & Median & $\begin{array}{c}\text { Third } \\
\text { quartile }\end{array}$ & Max \\
\hline \hline CH & 893 & 3683 & 7,356 & 7,386 & 9,650 & 19,104 \\
DE & 1888 & 8849.75 & 18,629 & 16,812 & 24,300 & 59,777 \\
ES & 6197 & 12423 & 28,109 & 25,050 & 33,777 & 133,591 \\
FI & 229 & 2119 & 7,354 & 4,818 & 12,392 & 31,304 \\
FR & 2005 & 10668.25 & 16,414 & 16,061 & 22,303 & 40,489 \\
HU & 3128 & 7205.75 & 15,675 & 11,485 & 26,851 & 32,486 \\
IT & 262 & 9035.75 & 23,896 & 15,651 & 32,379 & 132,537 \\
NL & 4385 & 10888 & 14,438 & 16,055 & 17,035 & 24,637 \\
NO & 1986 & 4120.75 & 10,246 & 6,579 & 15,439 & 30,056 \\
PT & 2348 & 4927 & 10,698 & 7,969 & 16,438 & 23,294 \\
UK & 0 & 5474 & 12,035 & 10,471 & 2,005 & 139,299 \\
\hline \hline
\end{tabular}

Table 5 Descriptive statistics on size (undergraduate students). Year 2003

Note: UK universities with zero undergraduate students correspond to universities which are specialist in postgraduate education. They will be excluded from analysis when appropriate. 


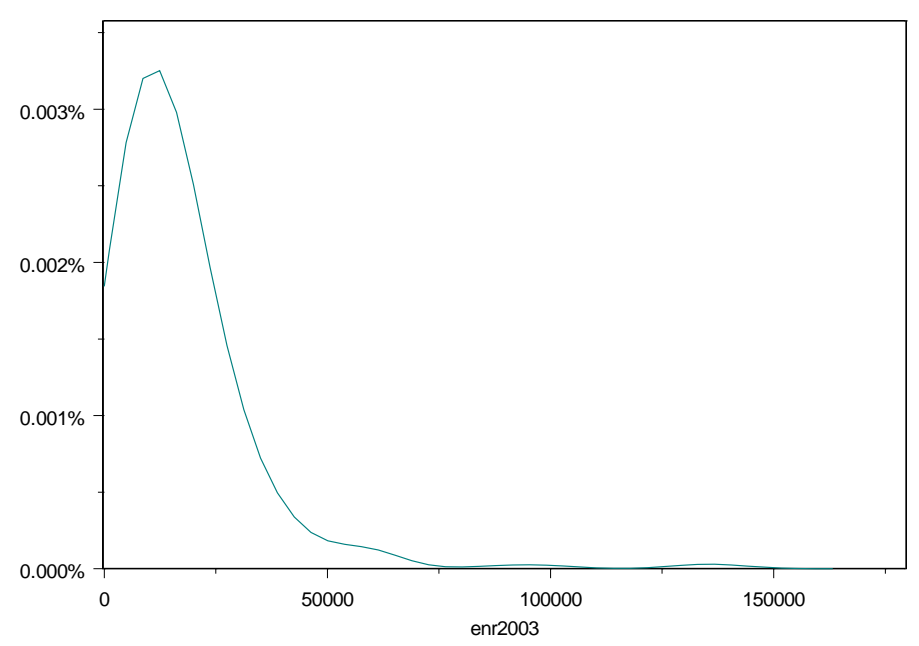

Figure 6 Kernel distribution of size (undergraduate students). Year 2003

Very large universities (beyond 50,000 undergraduate students) are in general old institutions in large cities, or in medium-sized cities attracting students from other regions. The largest universities in United Kingdom, Spain and Italy exceed 130,000 students (Table 5), an astonishing large number. The largest German university has around 60,000 students, the largest in France around 40,000. It seems that these very large institutions, as a general rule, are outlier in the distribution, while range of variation does not exceed 50-60,000 students (Figure 7).

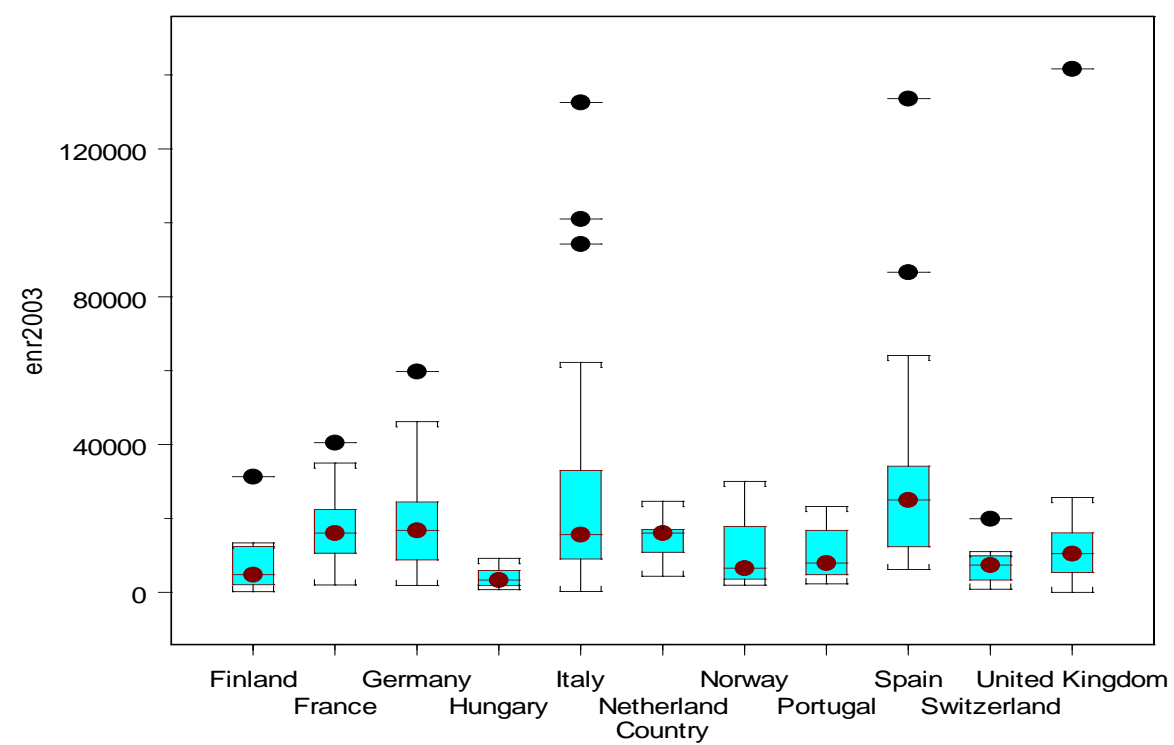

Figure 7 Boxplots of size (undergraduate students), year 2003 by country 


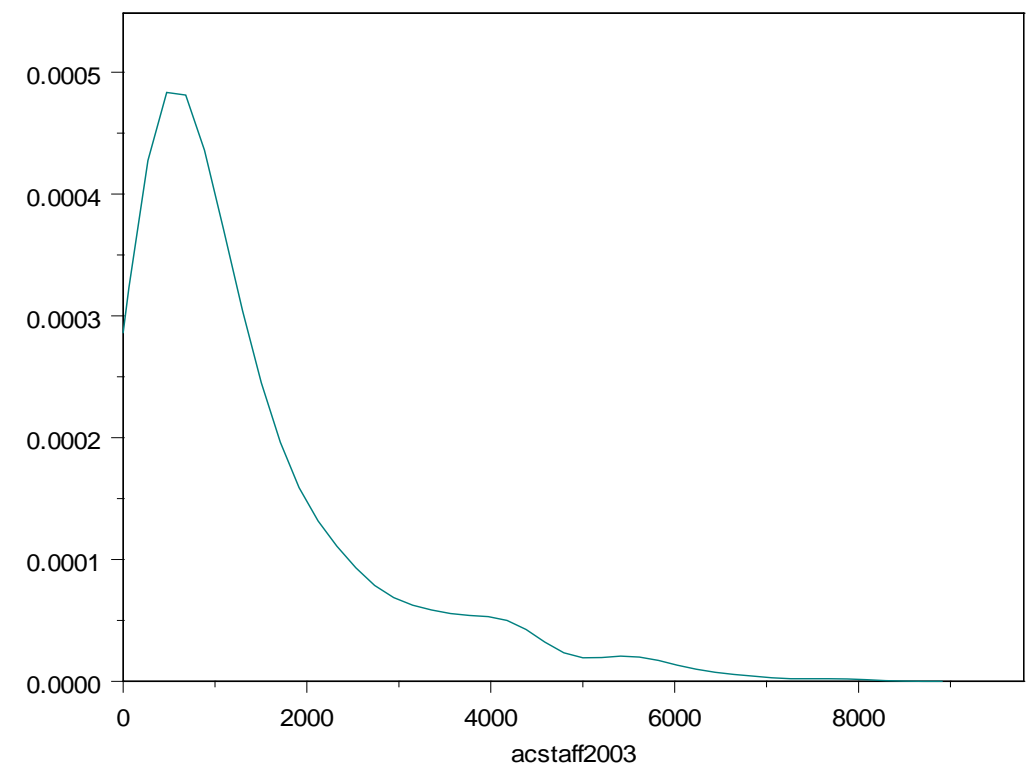

Figure 8 Kernel distribution of size (total academic staff). Year 2003

The size distribution with respect to academic staff, counted as heads (Figure 8) has a similar shape than the previous one, but the long tail on the right is fatter. Comparability of data is made extremely complex due to national definitions and the practical conditions of employment of academic staff.

An inspection of the national boxplots (Figure 9) shows that Germany, and particularly Switzerland, enjoy a larger number of inputs in terms of academic staff. In the case of Germany, overestimation of academic input is likely, however, since part of the staff, particularly research/ teaching assistants, work on a part time basis and/or on temporary positions.

In all other countries the median value is in the range 500-2000, with Italy, Spain and United Kingdom having a number of outliers. In the case of Italy, the figures are based only on permanent positions, while a large number of temporary positions are at work.

In the case of France, as it is evident from the boxplot, we find relatively small size with respect to academic staff. In fact, data for France refer only to full professors and maitres de conferences (associate professors), estimated to represent 67\% of all teachers and researchers at universities. In addition, these data do not include researchers working under the supervision of different institutions, such as large PROs and ministries. Summing up these idiosyncratic factors, French data are non comparable. 


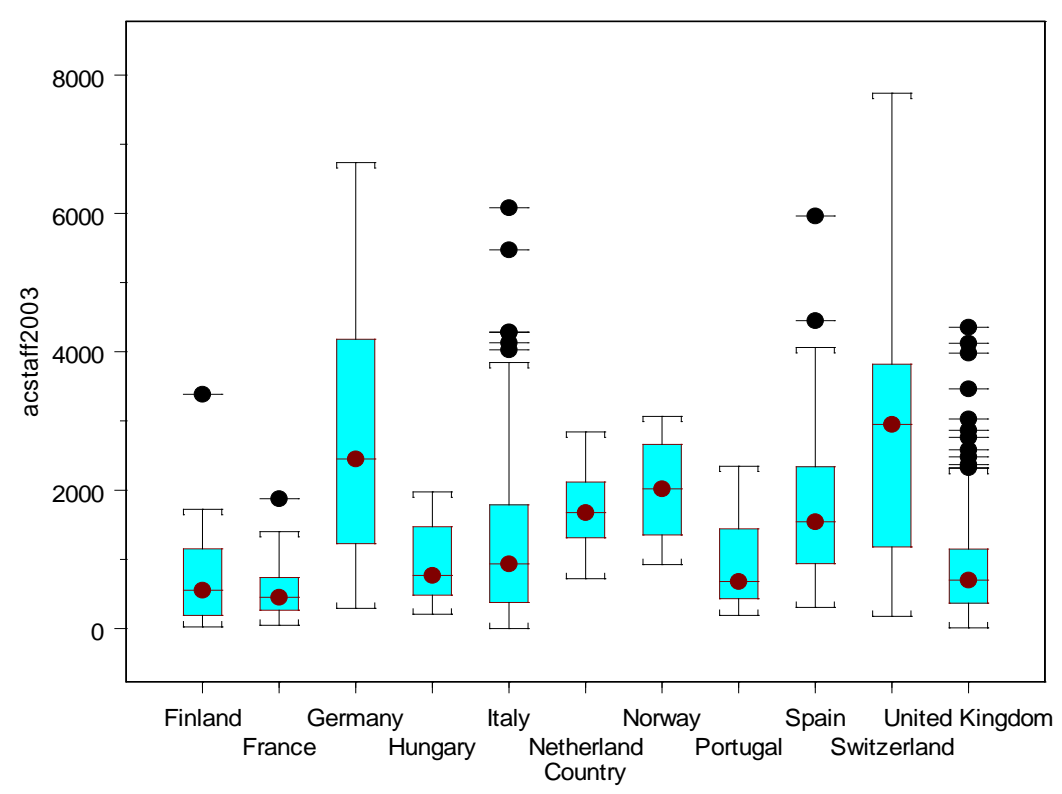

Figure 9 Boxplots of size (total academic staff), year 2003 by country

\begin{tabular}{|c|c|c|c|c|c|c|}
\hline Country & cr4 & cr8 & cr20 & $\begin{array}{c}\text { Herfindahl } \\
\text { index }\end{array}$ & $\mathbf{N}$ & $\begin{array}{c}\text { Normalized } \\
\mathbf{H} \\
\end{array}$ \\
\hline $\mathrm{CH}$ & 57.51 & 89.66 & - & 0.122 & 12 & 0.043 \\
\hline DE & 14.27 & 26.20 & 52.24 & 0.020 & 72 & 0.006 \\
\hline ES & 25.24 & 39.86 & 68.73 & 0.034 & 48 & 0.014 \\
\hline FI & 47.61 & 75.77 & 100.00 & 0.096 & 20 & 0.049 \\
\hline FR & 9.56 & 17.56 & 38.19 & 0.014 & 88 & 0.003 \\
\hline HU & 54.60 & 83.19 & - & 0.104 & 14 & 0.035 \\
\hline IT & 22.06 & 35.58 & 62.44 & 0.028 & 79 & 0.015 \\
\hline NL & 45.16 & 78.26 & - & 0.090 & 13 & 0.014 \\
\hline NO & 74.03 & 95.93 & - & 0.173 & 10 & 0.081 \\
\hline PT & 52.97 & 82.46 & - & 0.100 & 14 & 0.031 \\
\hline UK & 15.86 & 22.40 & 39.13 & 0.020 & 116 & 0.012 \\
\hline
\end{tabular}

Table 6 Concentration of universities by size (enrolled undergraduate students). Year 2003.

Table 6 offers various measures of concentration of students in universities: cr4, cr8 and cr20 are the concentration ratios, by country, which give respectively the percentage of students in the first 4, 8 or 20 universities ordered by decreasing number of enrolled students; whilst the Herfindahl index $(H)$, as showed in equation (1) gives the sum of the squares of the share of enrolled students of each individual university $\left(q_{i}\right)$. Finally, the Normalised Herfindahl index $\left(N_{-} H\right)$, described in equation (2) ranges from 0 to 1 and does not depend on $\mathrm{N}$ (the number of firms in the market) as the Herfindahl $(H)$ does. Usually, a value of the $N \_H$ index smaller than 0.1 indicates a non concentrated industry, and, as shown by Table 6 this is the case of all the European countries in the Aquameth dataset have a non concentrated number of undergraduate students in their universities ${ }^{2}$.

\footnotetext{
${ }^{2}$ We computed also the concentration indices reported in Table 6 on the variable Total academic staff and found the same kind of results of non-concentration.
} 


$$
\begin{aligned}
& H=\sum_{i=1}^{n} q_{i}^{2} \\
& N_{-} H=\frac{(H-1 / N)}{1-1 / N}
\end{aligned}
$$

Taking into account the size distribution and the concentration, we suggest a taxonomy based on the number of students or the number of academic staff (see more details in Table A1 and A2 in Appendix). The taxonomy includes five size categories:

$$
\begin{array}{ll}
\text { - } & \text { very small } \\
\text { - } & \text { small } \\
\text { - } & \text { medium } \\
\text { - } & \text { large } \\
\text { - } & \text { very large. }
\end{array}
$$

We have found that such a taxonomy represents appropriately the bulk of the distribution, leaving few cases to the extreme classes.

It appears that in all countries the medium size category (from 2.000 to 20.000 students) represents between $45 \%$ and $90 \%$ of the distribution, being the most representative. Medium-sized and large universities absorb the bulk of the distribution.

\begin{tabular}{lccccc}
\hline Country & Very large & Large & Medium & Small & Very small \\
\hline \hline CH & - & - & -0.0064 & 0.0309 & - \\
DE & -0.0329 & -0.0329 & -0.0194 & 0.0376 & - \\
ES & -0.0012 & -0.0004 & 0.0050 & - & - \\
FI & - & 0.0017 & 0.0042 & 0.0017 & 0.0063 \\
FR & - & 0.0002 & 0.0017 & - & - \\
HU & - & 0.0687 & 0.1031 & 0.0059 & - \\
IT & -0.0013 & 0.0022 & 0.0060 & 0.0501 & 0.0949 \\
NL & - & -0.0003 & 0.0009 & - & - \\
NO & - & -0.0003 & 0.0013 & -0.0015 & - \\
PT & - & 0.0014 & 0.0021 & - & - \\
UK & 0.0020 & 0.0036 & 0.0037 & 0.0065 & 0.0025 \\
\hline
\end{tabular}

Table 7 CAGR growth rates (enrolled students)

With respect to growth, the Aquameth project was able to calculate the CAGR over intervals of different length, from the initial year to the final year of the time series available (see Table 2 for details). As a general rule, rates of growth refer to the whole period 1996-2003.

The CAGR is calculated according to equation (3) where ny is the number of years in the interval being considered, end_value is the value of the variable of interest in the last year and start_value is its value in the first year of the interval.

$C A G R=\left(\frac{\text { end_value }}{\text { start_value }}\right)^{\left(\frac{1}{n y}\right)}-1$

Table 7 reports the average annual growth rates by country and size category.

Among the very small and small universities, Italy by far exceeds other countries, with a rate of $9.5 \%$ in the former case and $5 \%$ in the latter. Followers in the small category reach only $3 \%$ (Switzerland) or 3.8\% (Germany). A dynamics of fragmentation seems to be at place in Italy.

Medium sized universities, taken together, grow less than $1 \%$ per year in the period, and decrease by $2 \%$ per year in Germany. An exception can be found in Hungary, where medium-sized 
universities experienced an average annual growth of $10 \%$. Large and very large universities have a negative rate of growth almost everywhere, particularly in Germany (minus 3\% in both cases) and Spain. In Netherlands and Norway large universities also shrink, while in Italy large universities slightly grow and very large slightly decrease. Hungary is again an exception, insofar as large universities experienced an annual rate of growth of $7 \%$.

On average, the overall dynamics in Europe seems to be one of slow redistribution from large and very large universities, and entry of new small universities from the bottom.

\subsection{Subject mix}

The heterogeneity of university with respect to subject domains is a well-known issue in higher education, where a large part of the research on the field has focused on the features of different subject domains and on their classification (Becher and Trowler 2001), as well as on the dynamics of change and differentiation at this level, considered as a major driving force of higher education (Clark 1996). The issue is also quite relevant for institution-level studies since there is some empirical evidence that differences between HEI in subject mix might be large and account for large variations in the HEI-level indicators and thus significantly influence comparisons between individual institutions. Thus, a number of studies show that differences in costs per student between subject domains are large and systematic, with medicine on the top followed by natural sciences and technology, while social sciences and humanities have lower average costs (Jongbloed et al 2003; Johnes 1990). Also, using disaggregated data at the field level in the Swiss case, Filippini and Lepori (2007) show that differences between domains are systematically larger than differences between individual HEI and this pattern is consistent across a wide range of indicators, including students per professor, educational and total costs, number of $\mathrm{PhD}$ students and degrees.

However, the discussion has rarely gone beyond simple qualitative account of these differences. Thus, some classes of specialised institutions have been identified, like technical schools or business schools, but their role in the whole higher education system has yet to be analysed. Also, it is well-known that a major difference among HEI, which strongly impacts on their costs, is the presence or absence of a medical school, but to our knowledge no systematic mapping has been undertaken (at least in the European context).

A preliminary approximation done within the Aquameth project is based on the distinction between Generalist and Specialist universities. Based on previous analysis (Bonaccorsi and Daraio, 2007a) we define a Specialist if:

- more than $75 \%$ of undergraduate students are enrolled in just one field, or

- more than $90 \%$ of undergraduate students are enrolled in two fields.

We define a Generalist otherwise. We are aware that there may be "border" universities for which slightly changing the thresholds indicated above may strongly influence their status, and for this reason, we suggest to carry out some sensitivity analysis, by letting the thresholds vary in order to check if the classification remain stable. This classification indeed may be useful to carry out comparative analyses by separate categories. From a descriptive point of view, Table A3 in the Appendix shows the contingency table of categories per size of universities (as measured by the number of undergraduate students). As a general rule, one would expect that the larger the university the higher the probability that a university is generalist. However, a few countries, such as UK and Switzerland also have specialist universities of large and very large size. This is an interesting indicator of the degree of differentiation of the university profile. In fact, specialist universities may be tilted towards entering into many fields of education during their life cycle, unless the institutional context puts a prize on fostering specialization even at large size. 
In Aquameth, we did an effort to collect data disaggregated by scientific fields, using a simple classification in four domains (human and social sciences; technical sciences; natural sciences; medicine). This proved to be possible for most countries in the sample for students and, for a number of them, for staff; to some extent, it was also possible to map Web of Science publications data to this scheme, even if one needs to consider the different coverage of WOS across scientific domains.

Methodologically, the whole issue is complicated by the multi-input and multi-output nature for HEI; thus, there is no reason why the distribution of students across subjects should match that of scientific publications or staff, even if these are somewhat related. The simplest choice in terms of availability of data, namely using the number of students by domain to characterize subject mix (Bonaccorsi and Daraio 2007), can provide misleading results if differences in orientation towards education vs. research between domains are large and systematic, as some data suggest in the Swiss case (Filippini and Lepori 2007).

Ideally one should calculate the distribution of different types of inputs and outputs and then explore their relationship, an option which is hardly possible because of the limitations of the available data. We then resorted to the simpler strategy of adopting the number of academic staff (in Full Time Equivalents; FTE) as the basic measure of the effort invested in each domain. The advantage is that these data are normally available and more robust than budgetary data; of course, their main limitation is that one disregards the differences by domain in types of costs (related for example to different share of capital costs) and in staff composition.

Preliminary analysis on five countries (Finland, Italy, Netherlands, Norway and Switzerland) and for the year 2001 display some quite interesting patterns, as well as variations between subjects and considered countries (Lepori and Baschung 2008).

\begin{tabular}{|c|c|c|c|c|c|}
\hline Type & Category & Subclasses & N. & Staff FTE & Avg. Staff \\
\hline Specialist & Natural sciences HEI & & 1 & & \\
\hline \multirow[t]{2}{*}{ Specialist } & Technical HEI & Pure technical HEI & 10 & 10812 & 1081 \\
\hline & & Natural-technical HEI & 4 & 18481 & 4620 \\
\hline \multirow[t]{2}{*}{ Specialist } & Humanities and Social & Business schools & 3 & 3372 & 1124 \\
\hline & Sciences HEI & Other & 19 & 5017 & 264 \\
\hline Specialist & Medical HEI & & 2 & 1268 & 634 \\
\hline General & HEI with strong Medicine & & 8 & 18626 & 2328 \\
\hline General & HEI with Medicine & & 44 & 135775 & 3086 \\
\hline General & General HEI without Medicine & & 37 & 34930 & 944 \\
\hline Total & Total & & 128 & 228281 & 1797 \\
\hline
\end{tabular}

Table 8. Classes of HEI by subject mix (Finland, Italy, Netherlands, Norway and Switzerland, year 2001)

Thus, specialised institutions are largely a specific pattern of technical sciences, where practically all institutions with a large technical department are specialised in the field (possibly also with a large natural sciences department); a second group of specialised HEI is in human and social sciences, but these are smaller and account in all countries for a small share of the total staff in the field. Specialised institutions are partially absent in natural sciences (the only case being SISSA in Trieste) and in medicine (small HEI in Italy).

The second major pattern refers to medicine, which shows a different concentration pattern. Namely, in the sample considered here only $40 \%$ of the institutions have a sizeable medical department (larger than 200 FTE of staff), while the ten institutions with the largest departments concentrate about half of the total staff in the field. However, these are not specialised, but are in fact the largest generalist universities in their country, like Rome in Italy, Zurich in Switzerland, Oslo in Norway.

The final group of institutions is composed of universities without a significant medical department, but including the other domains (except maybe technology); the typical profile of these institutions 
is having $2 / 3$ of the staff in human and social sciences and 1/3 in natural sciences and technology; these are in the average small and younger than the general HEI with medicine.

These preliminary results, which need to be further investigated, indicate that at the level of large subject domains, there are distinct pattern of specialisation, which are probably the result of longlasting historical process, like medicine being in the core of the older universities and growing there, while technical sciences have been institutionalised in specific institutions in more recent times. Significant differences emerge also among countries, some of them showing a stronger specialisation of HEI (Finland and Netherlands), while in Italy the generalist university is the dominant model and even technology is mostly located in generalist institutions.

Clearly further research is needed here to build a full multi-criteria classification.

\subsection{Funding structure}

The analysis of sources of funding is another difficult exercise, due to lack of comparability of administrative definitions. Appendix D offers a detailed description of national definitions of items in the financial reporting of universities. There are a few important remarks:

- Other funds in UK includes donations, which are a significant portion of the total budget for many universities, and revenues from goods and services (Crespi, 2007);

- Private funding in Portugal includes contract research granted by the government in a competitive way; it is not possible to disentangle the two components (Teixeira et al., 2007);

- Private funding in Finland includes funding from non government agencies, in addition to firms;

- Student fees in Germany include a large number of other revenues (especially revenue from medical treatment in university hospitals) and are not comparable.

Given these remarks, it is almost impossible to strictly compare the share of funding coming from the private sector across all the sample, and consequently the other shares.

With this caution, there are several interesting features which appears from Table 9:

- universities rely on government funding for $47 \%$ in UK, while in all other countries the range is between $64 \%$ (Portugal) and 93\% (Norway); Germany is at 56\% but the data are not comparable;

- countries in which dependence on government funding is at intermediate level, such as Italy, UK, and Spain, rely on student fees for a share between $15 \%$ and $24 \%$; Germany is at $43 \%$ but again the date cannot be compared;

- Scandinavian countries (Finland, Norway, Netherlands) and Hungary have negligible student fees;

- Private funding, with the exception of Portugal and Finland that are not comparable for the reasons above, does not exceed $6 \%$ of the total funding.

It seems that universities do not have many room for manoeuvring in almost all countries, with the exception of UK. If student fees cannot be increased, either because they are already large (Italy, UK, Spain), or because they are not politically accepted (Finland, Norway, Netherlands, Hungary), and if private funding does not exceed a limited share around 5-6\%, then universities must totally rely on government funding.

However, there is some evidence that governments have altered over time the composition of total research funding, moving from general (block) funding to project funding (Geuna, 1999; Lepori et al. 2006; 2007; Potì and Reale, 2007). Universities may alter this composition at their advantage. 


\begin{tabular}{lccccccccc}
\hline Category of funding & CH & ES & FI & HU & IT & NL & NO & PT & UK \\
\hline \hline Tuition and fees & 2.09 & 17.67 & $\mathrm{nr}$ & $\mathrm{nr}$ & 14.72 & 5.61 & 0.00 & 5.82 & 23.69 \\
Government funding & 83.14 & 67.10 & 72.94 & 89.15 & 75.37 & 75.89 & 92.63 & 63.90 & 47.05 \\
EU and other inter. Funding & 1.81 & 2.69 & 4.42 & 3.26 & 0.26 & 1.33 & 1.27 & 6.06 & 2.42 \\
Private funding & 8.78 & 1.44 & 22.64 & 6.54 & 5.97 & 6.87 & 3.76 & 24.23 & 6.29 \\
Asset revenues & 4.17 & 0.54 & 0.00 & 0.00 & 2.03 & 0.00 & 0.00 & 0.00 & 1.53 \\
Other funds & 0.00 & 10.56 & 0.00 & 1.06 & 1.65 & 10.30 & 2.34 & 0.00 & 19.01 \\
\hline Total & 100 & 100 & 100 & 100 & 100 & 100 & 100 & 100 & 100 \\
\hline \hline
\end{tabular}

Table 9 Sources of funding (percentages).

Note: $n r=$ not relevant.

\subsection{The differentiation of European universities}

The differentiation of universities in their offering profile may be described along several dimensions. We focus here on one of them, namely the proportion between postgraduate education, particularly doctoral, and undergraduate education. This simple indicator is very informative with respect to the strategic choice of universities. To a certain extent, doctoral students compete with undergraduate for professor time and attention, and for physical and laboratory space. In fields characterized by international competition and mobility of $\mathrm{PhD}$ candidates, universities become attractive for $\mathrm{PhD}$ only if they have dedicated staff and facilities, and teach courses in English. Consequently, university that want to compete internationally in doctoral education must keep the ratio between $\mathrm{PhD}$ and undergraduate above a certain threshold (Bonaccorsi, 2008).

Figure 10 illustrates the distribution of $\mathrm{PhD}$ students by countries and shows that European universities have a large variability, but most variability takes place in countries that have actively promoted policies to differentiate universities along this dimension. These include Switzerland, UK, Netherlands, and Hungary. In the former case, part of the variability depends on the traditional propensity of students in Switzerland to carry out a doctoral course during their early career, in order to improve the entry conditions in the job market. 


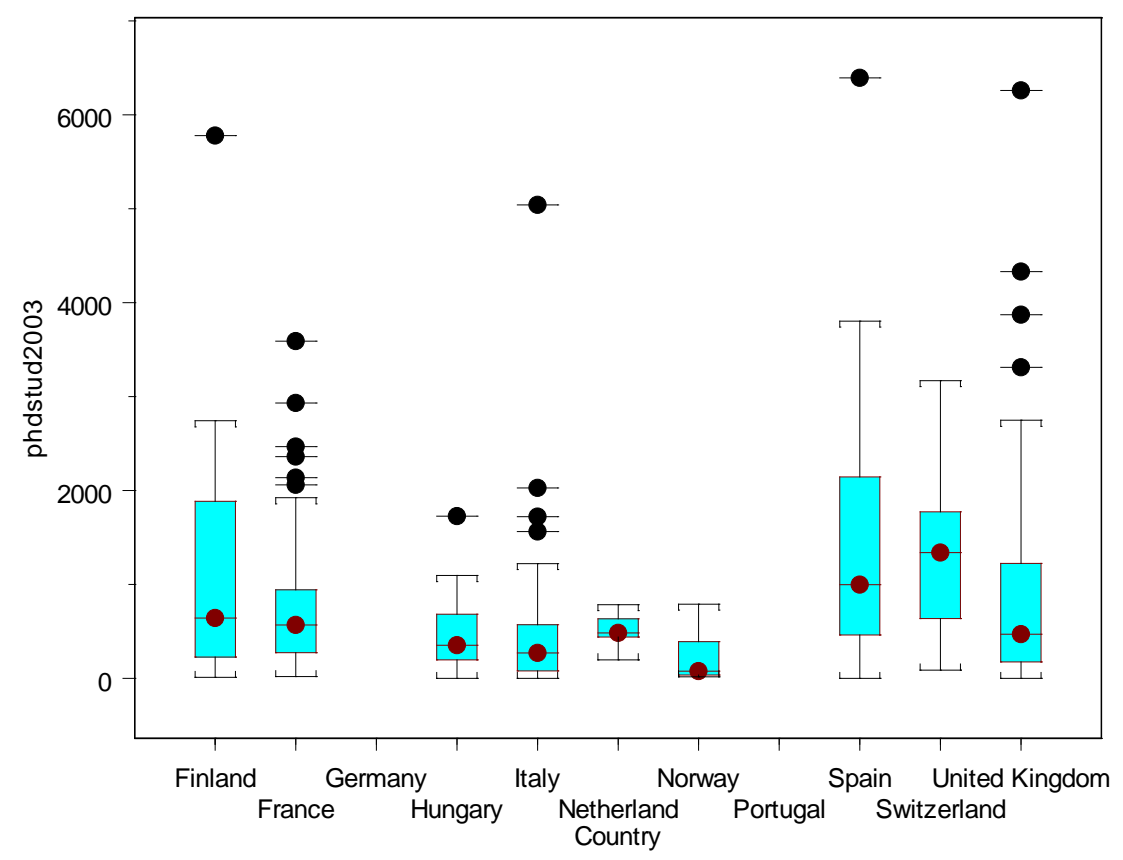

Figure 10 Boxplots of PhD students by country. Year 2003

\begin{tabular}{lcccc}
\hline Country & $\begin{array}{c}\text { Average } \\
\text { value }\end{array}$ & $\begin{array}{c}\text { Maximum } \\
\text { value }\end{array}$ & $\begin{array}{c}\text { Standard } \\
\text { Deviation }\end{array}$ & $\begin{array}{c}\text { Variation } \\
\text { coefficient }\end{array}$ \\
\hline \hline $\mathrm{CH}$ & 2.71 & 5.16 & 1.57 & 2.45 \\
$\mathrm{ES}$ & 0.50 & 1.37 & 0.26 & 0.07 \\
$\mathrm{FI}$ & 0.67 & 1.60 & 0.35 & 0.12 \\
$\mathrm{FR}$ & 0.63 & 3.11 & 0.60 & 0.36 \\
$\mathrm{HU}$ & 0.36 & 1.15 & 0.43 & 0.18 \\
$\mathrm{IT}$ & 0.29 & 3.05 & 0.37 & 0.14 \\
$\mathrm{NL}$ & 1.59 & 4.06 & 0.83 & 0.69 \\
$\mathrm{NO}$ & 0.65 & 2.22 & 0.70 & 0.49 \\
$\mathrm{PT}$ & 0.44 & 0.75 & 0.18 & 0.03 \\
$\mathrm{UK}$ & 1.42 & 43.48 & 4.18 & 17.46 \\
\hline
\end{tabular}

Table 10 Indicators of structural differentiation of universities in doctoral education. Some descriptive statistics on the indicator $\mathrm{PhD}$ recipients per 100 undergraduate students

This is evident by inspecting the average value of the ratio $\mathrm{PhD}$ recipients per 100 undergraduate students (Table 10), and confirmed by the coefficient of variation of the ratio across countries, which is at very high levels for Switzerland and UK and still larger than in other countries for Netherlands. While there are universities that reach high levels of the ratio in Italy and France as well, in these countries they are exceptions that do not influence the overall distributions.

The fact that undergraduate and postgraduate education may be subject to trade-offs is visible by inspecting Figure 11. This figure plots the load from $\mathrm{PhD}$ education $(\mathrm{PhD}$ students per unit of academic staff) against the load for undergraduate education (Undergraduate students per unit of academic staff). A slightly positive correlation emerges (Pearson correlation= 0.151) on the aggregate data. However, when we move away from the region of low load, it is clear that universities with higher than average commitment to $\mathrm{PhD}$ do not have large undergraduate load. 
Almost all countries are found along the axis or the negative diagonal, with the interesting exception of France. Here the large capacity in managing doctoral education may be due to research staff collaborating with universities but not included in academic staff (e.g. CNRS or INSERM).

In general, Italian universities are better found along the vertical axis (higher student load), while British and Swiss universities are more likely to lie close to the horizontal axis (higher PhD load).

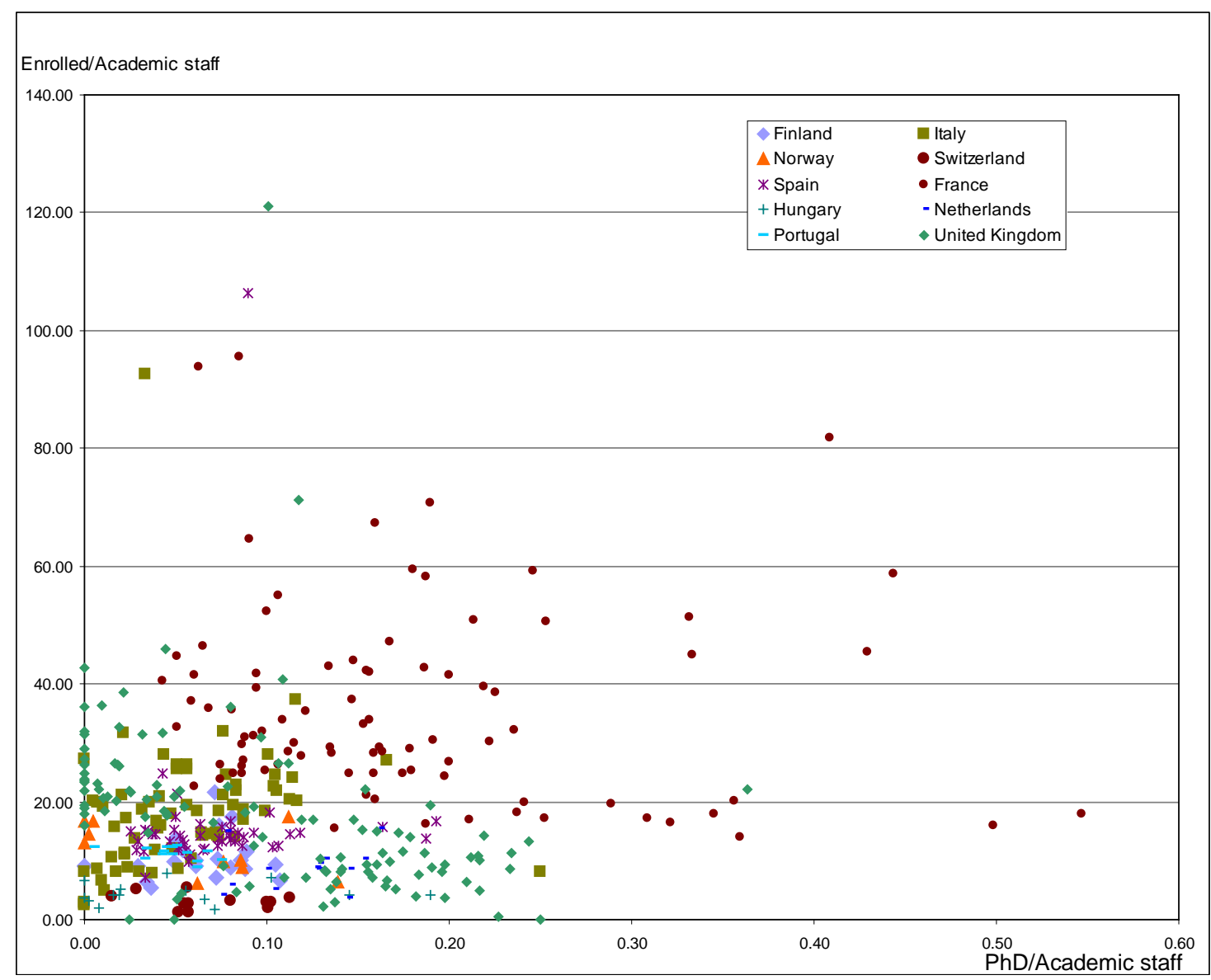

Figure 11 Plot of PhD per academic staff vs undergraduate per academic staff - Total

\subsection{The scientific productivity of European universities}

By scientific production it is assumed the publication of international papers in refereed journals (Figure 12). This definition is clearly very crude, does not give enough recognition to Human and Social Sciences (see e.g. Hicks, 2004), and ignores non-ISI publications. Also, crude indicators such as publications per unit of academic staff may be misleading either due to the numerator (differences in pattern of scientific production across disciplines, hence across universities with different subject mixes) and to the denominator (differences in time involvement of academic staff into research activity). At the same time, data at national level should not be heavily biased by differences in subject mix, given that the predominant model is the generalist university ranging several disciplines. Anyway, presenting the distribution of data (boxplot), instead of aggregate data at national level, permit close investigation and correction of possible errors. 
We consider a simple indicator of scientific productivity, namely the number of international (ISI) publications per unit of academic staff, and we explore the distribution of this indicator by country (Figure 13). Data for France and Germany are missing.

When coming to productivity, i.e. number of publications per unit of academic staff (Figure 13), the Dutch system seems to outperform others, followed by United Kingdom. All other countries exhibit a similar level of the median value, with Norway and Finland slightly better. Italy has several outliers with productivity close to UK leaders.

If we examine the trade off between research production and teaching overload, it is clear from Figure 14 that a negative relation emerges.

A closer inspection shows that large universities are subject to a more severe trade-off, since very few of them are located along the horizontal axis of scientific productivity, while almost all of them exhibit high values of student load. The trade off seems to be less stringent, although still in place, for medium-sized universities.

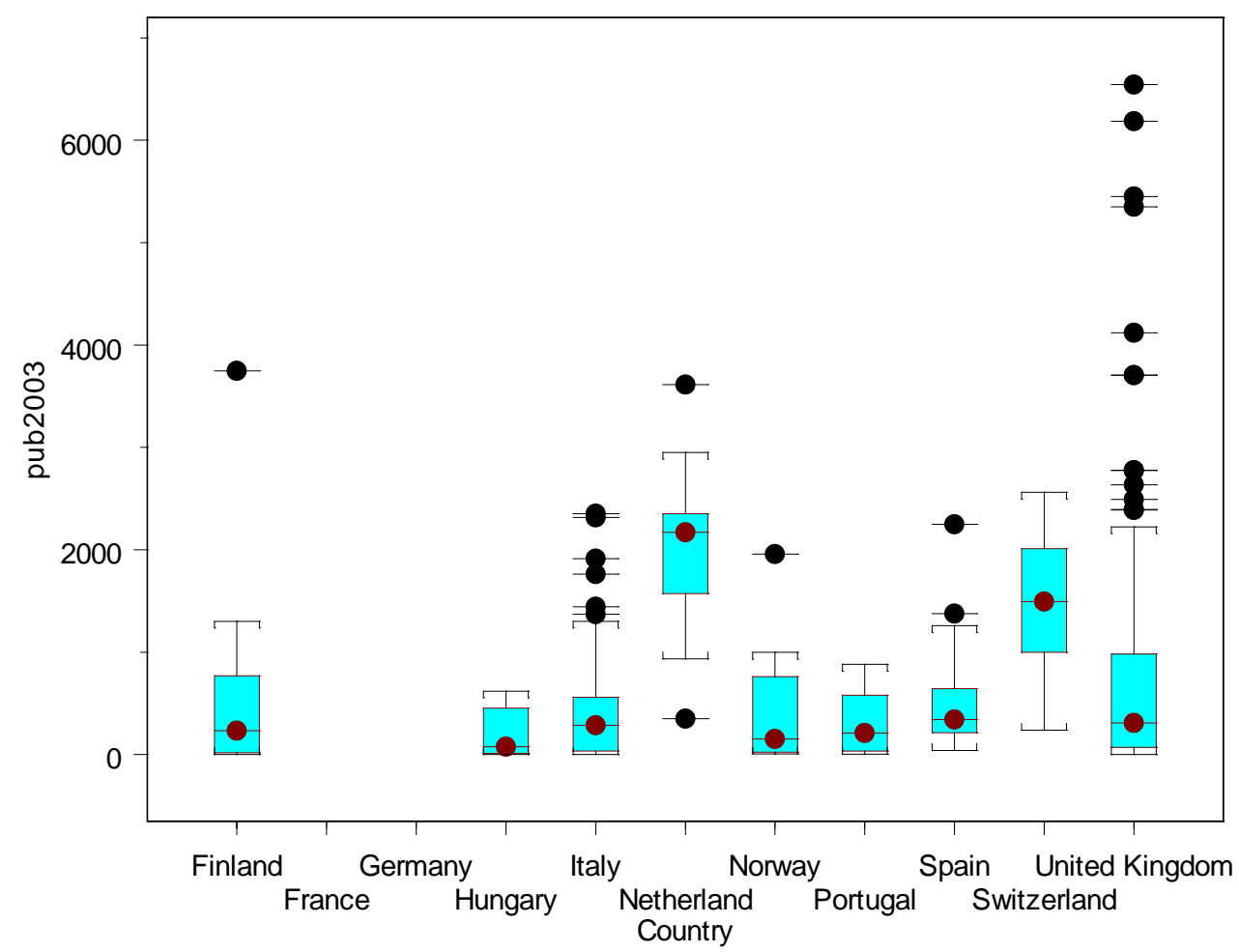

Figure 12 Boxplots of total publications by country. Year 2003 


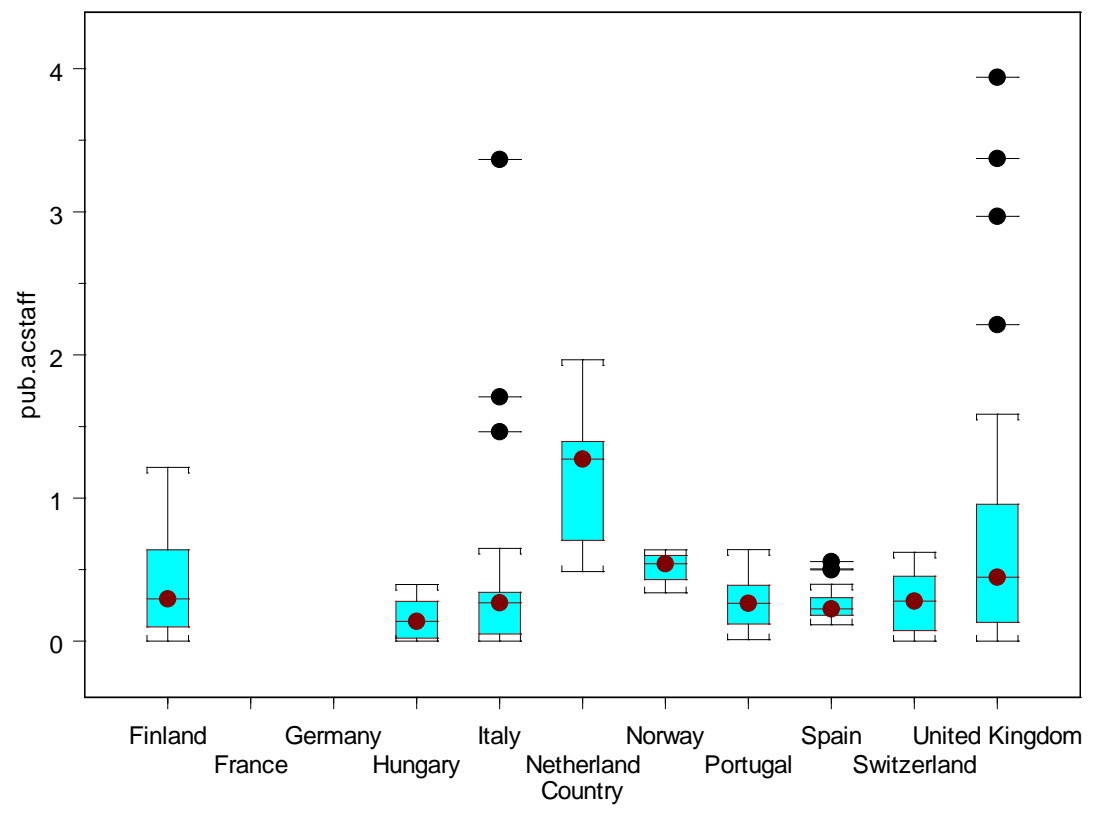

Figure 13 Boxplots of publications per academic staff by country. Year 2003

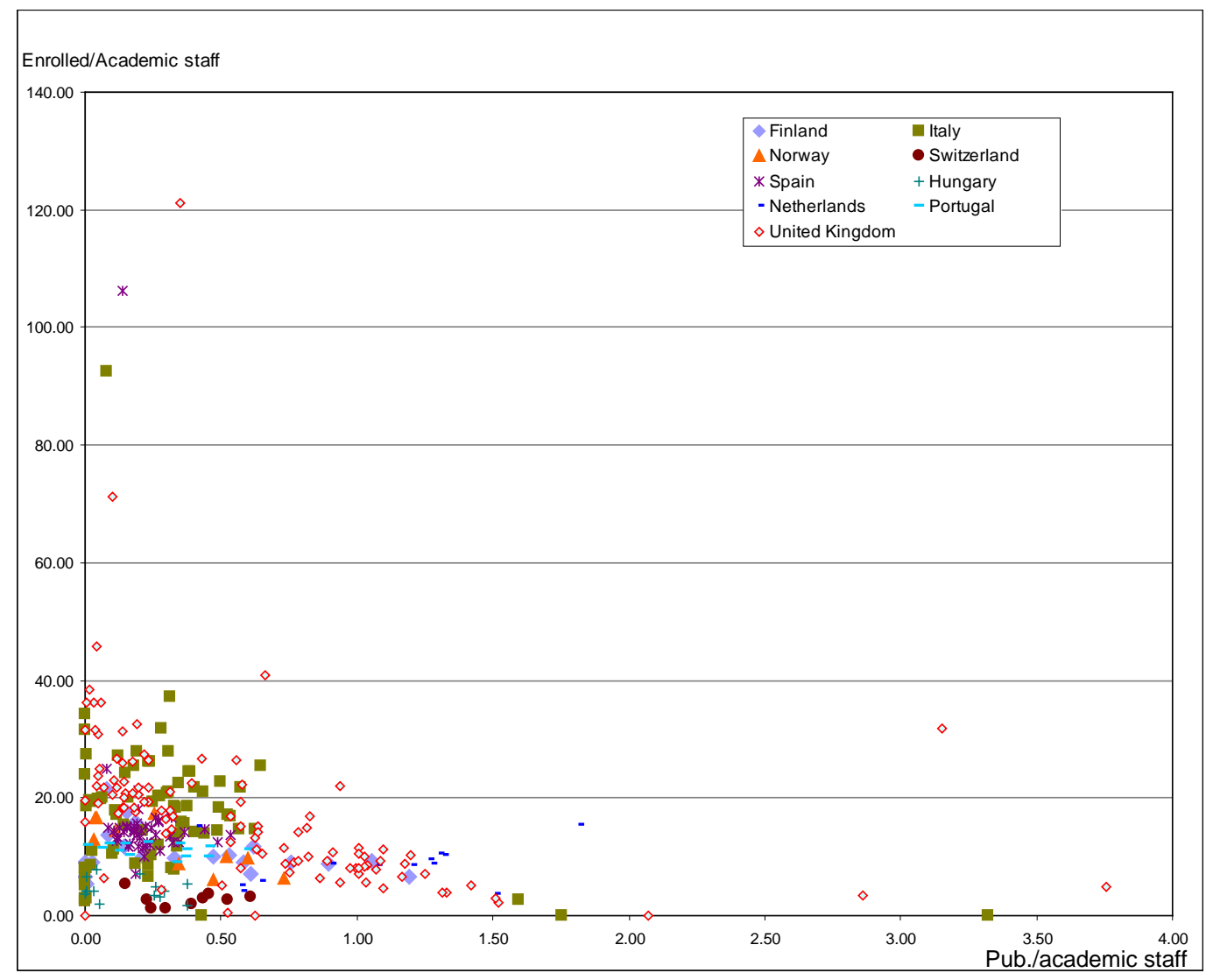

Figure 14 Plot of publication intensity vs undergraduate per academic staff - Total 


\section{Conclusions}

In a recent analysis of funding ground breaking research, summarizing the literature, Heinze has noted that "short-term funding tends to encourage the exploitation mode which favours risk-averse research strategies and leads to proximate and often predictable outcomes, while high-impact research seems to be connected to the explorative mode conducted using long-term funding” (Heinze, 2008, p.304).

When the Aquameth project was selected by the Executive Committee of the PRIME Network of Excellence, an anonymous referee, while supporting the funding decision, wrote that such a project had one chance out of five to be successful. It clearly would have not been funded under a short term, exploitation-mode funding scheme. As a matter of fact, the initial project started with six countries, expanded to eleven in a successive stage, and is now involving even more countries. In addition to a full book, the project has generated a few dozens research papers, some of which already published, and a fully integrated original dataset.

The micro approach followed in the project has made it possible to close the gap between individual case studies and studies based on aggregated national statistics. There is a great potential for rigorous micro data gathering and data analysis exercises at European level: the Aquameth project has showed that this kind of approach is both feasible and useful. The project also demonstrated that the integration of micro-data at European level, taking into account all possible comparability issues, is feasible.

There is still a large research agenda for full scale validation, standardization and exploitation of data, in addition to some work to complete time series.

At the same time, it was not only a matter of collection of data and indicators. The project combined this craftman-like work with new methodologies in econometrics (using both parametric and nonparametric tools), long term theoretical investigation of the evolution of higher education and knowledge production and a careful attention to relevant policy debate.

This paper is the first large scale investigation of European universities based on microdata. Starting the exploitation of an original, rich and detailed database created within the Aquameth Project (under the European Network of Excellence PRIME), it presents indicators and analysis of historical trajectories, concentration, distribution, growth rates dynamics, differentiation and scientific productivity carried out on the universe of higher education institutions in eleven countries.

In a middle term perspective, we hope that the experimental work carried out by the Aquameth project may be standardized and normalized, in a professional way, at the level of national and European statistical offices.

The evidence showed in this paper support the urgent need for policy decisions based on empirical evidence at the microlevel, to complement the broad analysis carried out at aggregate (national) level.

\section{Acknowledgements}

The authors wish to thank Alessandro Daraio for his competent research assistance and Philippe Laredo for encouragement and helpful discussions. Funding support by the European Commission through the PRIME Network of Excellence (Aquameth project) is gratefully acknowledged. Previous versions of this paper have been presented at the DIME Scientific Workshop, Strasbourg, April 2008; $2^{\text {nd }}$ ENID PRIME S\&T Indicators Conference, Oslo, May 2008, at several seminars at SISTER-RIDE (Stockolm), INGENIO (Valencia) and meetings at DG Research, European Commission. 


\section{References}

Amaral A., G.A.Jones and B.Karseth (eds.) (2002) Governing higher education: National perspectives on institutional governance. Dordrecht, Kluwer Academic Publishers.

Amaral, A., Meek V.L., Larsen I. (2003) (eds.) The Higher Education Managerial Revolution?, Kluwer Academic Publisher, Amsterdam.

Baum JAC. 1996. Organizational Ecology. In Handbook of Organization Studies, Clegg SR, Hardy C, Nord WR (eds.). Sage: London.

Becher, Tony and Maurice Kogan (1992) - Processes and Structure in Higher Education, Routledge, London

Becher T., Trowler P. (2001), Academic Tribes and Territories, Open University Press, London.

Bonaccorsi A. (2008), Division of academic labour is limited by the size of the market. Strategy and differentiation of European universities in doctoral education, in McKelvey M. and Deiaco E., edited by, Learning how to compete in European universities, Edward Elgar, Cheltenham (UK).

Bonaccorsi A., Daraio C. (2004), Econometric approaches to the analysis of productivity of R\&D systems. Production functions and production frontiers, in H.F. Moed, W. Glanzel and U Schmoch (eds.), Handbook of Quantitative Science and Technology Research, Kluwer Academic Publishers, 51-74.

Bonaccorsi A., Daraio C. (2007a), eds, Universities and Strategic Knowledge Creation. Specialization and Performance in Europe, Edward Elgar Publisher, Cheltenham, PRIME Series on Research and Innovation Policy in Europe.

Bonaccorsi A., Daraio C. (2007b), Theoretical perspectives on university strategy, In Bonaccorsi and Daraio (2007a).

Bonaccorsi A., Daraio C. (2007c), Universities as strategic knowledge creators: Some empirical evidence, In Bonaccorsi and Daraio (2007a).

Bonaccorsi A., Daraio C. (2008), " The differentiation of the strategic profile of higher education institutions. New positioning indicators based on microdata”, Scientometrics, Vol. 74, No. 1 (January, 2008).

Bonaccorsi A., Daraio C., Lepori B. and Slipersaeter S. (2007), Indicators on individual Higher Education Institutions. Addressing data problems and comparability issues, Research Evaluation, 16 (2), 66-78.

Bonaccorsi, A., Daraio, C. and L. Simar (2006), Size, scope and trade-off in the productivity of universities: an application of robust nonparametric methods to Italian data. Scientometrics, 66(2), 389-410.

Bonaccorsi A., Daraio C. and Simar L. (2007), Productivity and efficiency of European universities. Exploring trade-offs in the strategic profile, In Bonaccorsi and Daraio (2007a).

Braxton, J.M. (1996). Contrasting perspectives on the relationship between teaching and research. New Directions for Institutional Research, 90, 5-15.

Brinkman, Paul and Larry Leslie (1986) - "Economies of Scale in Higher Education: Sixty Years of Research", The Review of Higher Education, Vol. 10, Fall, No 1, 1-28 
Bruderl J, Schussler R. 1990. Organizational Mortality: The Liabilities of Newness and Adolescence. Administrative Science Quarterly 35(3): 530-547.

Clark B.R. (1983) The higher education system: Academic organization in cross-national perspective. Berkeley, The University of California Press.

Clark B. (1996), Diversification of Higher Education: Viability and Change, in Meek, V.L., L. Goedegebuure, O. Kivinen \& R. Rinne (eds. 1996), The mockers and mocked. Comparative perspectives on differentiation, convergence and diversity in higher education. Oxford: Pergamon.

Clark, B.R. (1997). The modern integration of research activities with teaching and learning. Journal of Higher Education, 68(3), 241-255.

Clark, B. R. (1998) The Entrepreneurial University. Oxford: Pergamon Press.

Cohn, E.; Rhine, S. and Santos, M. 1989. "Institutions of Higher Education as Multi-Product Firms: Economies of Scale and Scope”. The Review of Economics and Statistics, 284-290

Crespi G. , (2007), The UK knowledge production function, In Bonaccorsi and Daraio (2007a).

De Weert, E. (1999). Contours of the emergent knowledge society: theoretical debate and implications for higher education research. Higher Education, 38, 49-69.

Dundar, Halil and Darrell Lewis (1995) - "Departmental Productivity in American Universities: Economies of Scale and Scope”, Economies of Education Review, Vol 14; No 2, 119-144

Ehrenberg R. G. (2004), Econometric studies of higher education, Journal of Econometrics, 121, 19-37.

Filippini M., Lepori B. (2007) Cost structure, economies of capacity utilization and scope in Swiss Higher education institutions, in Bonaccorsi and Daraio, eds, (2007a).

Geuna A. (1999), The Economics of Knowledge Production: Funding and the Structure of University Research, Edward Elgar, Cheltenham.

Griliches Z., (1994) Productivity, R\&D, and the data constraint, American Economic Review, 84(1) (March), pp. 1-23.

Hannan MT, Freeman J. 1977. The Population Ecology of Organizations. American Journal of Sociology 82: 929-964.

Hannan MT, Freeman J. 1984. Structural Inertia and Organizational Change. American Sociological Review 49: 149-164.

Hannan MT, Freeman J. 1989. Organizational Ecology. Harvard University Press: Cambridge.

Heinze, T. (2008), How to sponsor ground-breaking research: a comparison of funding schemes, Science and Public Policy, 35 (5), 302-318.

Henderson AD. 1999. Firm Strategy and Age Dependence: A Contingent View of Liabilities of Newness, Adolescence and Obsolescence. Administrative Science Quarterly 44(2): 281-314.

Hicks D. (2004) The four literatures of social science, in H.F. Moed, W. Glanzel and U Schmoch (eds.), Handbook of Quantitative Science and Technology Research, Kluwer Academic Publishers, 51-74., 473-496. 
Huisman, J. and Kaiser F.(2001) (eds.) Fixed and fuzzy boundaries in Higher Education. A comparative study of (Binary) structures in nine countries. Den Haag, Adviesraad voor het Wetenschapsen

Johnes J. (1990), “Unit costs: some explanations of the differences between UK Universities”. Applied Economics 22: 853-862.

Jongbloed B. Salerno C., Kaiser F. (2003), Kosten per Student. Methodologie, schattingen en een internationale Vergelijnk, CHEPS, Twente.

Kantrowitz, B. (2003): Learning the Hard Way: Universities Around the World are Plagued by a Host of Intractable Problems - Except in America. What are They Doing Right? In: Newsweek (15.09.2003). pp. 6067

Knorr-Cetina K. (1995), Laboratory Studies. The cultural approach to the study of science, in Jasanoff, S., G. E. Markle, J. C. Petersen and T. Pinch, Eds. (1995), Handbook of Science and Technology Studies, London, Sage Publications, 140-166.

Kyvik S. (2004) Structural changes in Higher Education systems in Western Europe. Higher Education in Europe, 29 (3), 393-409.

Kyvik S., Skovdin O.-J. (2003) Research in the non-university higher education sector - tensions and dilemmas. Higher Education 45, 203-222.

Larédo P. and Mustar P. (2001), eds, Research and Innovation Policies in the New Global Economy, An International Comparative Analysis, Cheltenham: Edward Elgar.

Lepori B., Baschung L. (2008), Subject mix in higher education institutions: a first empirical analysis from the AQUAMETH database, paper presented at the ENID-PRIME Conference on S\&T Indicators, Olso, May 2008.

Lepori B., Benninghoff M., Jongbloed B., Salerno C., Slipersaeter S. (2007) Changing models and patterns of higher education funding: some empirical evidence. In A.Bonaccorsi and C.Daraio (eds.) (2007a).

Mairesse J, and Griliches Z., (1998), Production Functions: The Search for Identification, in Z. Griliches, Practising Econometrics : Essays in Method and Application, Edward Elgar, 383-411.

Marsh L. C. (2004), “The econometrics of Higher Education: editor’s view”, Journal of Econometrics, 121, 1-18.

Mintzberg H. (1979), The structuring of organizations: A synthesis of the research, Prentice-Hall (Englewood Cliffs N.J.).

Potì B.and Reale E. (2007) "Changing allocation models for public research funding: an empirical exploration based on project funding data”, Science and Public Policy, vol 34 N6.

Sarrico, C. S., Dyson, R. G., 2004. "Restricting virtual weights in data envelopment analysis.” European Journal of Operational Research 159 (1), 17-34.

Teichler, Ulrich (1988) - Changing Patterns of the Higher Education System, Jessica Kingsley Publishers, London 
Teixeira P., Cardoso M.F., Sarrico C.S., Rosa M.J. (2007), The Portuguese public university system: on the road to improvement?, in Bonaccorsi and Daraio (2007a).

Vidal, J., Quintanilla, M.A. (2000). The teaching and research relationships within institutional evaluation. Higher Education, 40, 221-229.

Winston, Gordon C (1999), "Subsidies, hierarchy and peers: The awkward economics of higher education" Journal of Economic Perspectives; 13, 1; pp. 13-36 
APPENDIX A. Detailed Tables

\begin{tabular}{|c|c|c|c|c|c|c|}
\hline Country & & Very large & Large & Medium & Small & Very small \\
\hline & Number & niversities & & & & \\
\hline \multirow[t]{2}{*}{$\overline{\mathrm{CH}}$} & Number & - & 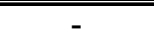 & 10 & 2 & 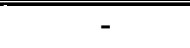 \\
\hline & $\%$ & - & - & 83.33 & 16.67 & - \\
\hline \multirow[t]{2}{*}{ DE } & Number & 1 & 26 & 44 & 1 & - \\
\hline & $\%$ & 1.39 & 36.11 & 61.11 & 1.39 & - \\
\hline \multirow[t]{2}{*}{ ES } & Number & 6 & 21 & 21 & - & - \\
\hline & $\%$ & 12.50 & 43.75 & 43.75 & - & - \\
\hline \multirow[t]{2}{*}{ FI } & Number & - & 1 & 14 & 3 & 2 \\
\hline & $\%$ & - & 5.00 & 70.00 & 15.00 & 10.00 \\
\hline \multirow[t]{2}{*}{ FR } & Number & - & 33 & 55 & - & - \\
\hline & $\%$ & - & 37.50 & 62.50 & - & - \\
\hline \multirow[t]{2}{*}{$\mathrm{HU}$} & Number & - & 5 & 9 & & - \\
\hline & $\%$ & - & 35.71 & 64.29 & - & - \\
\hline \multirow[t]{2}{*}{ IT } & Number & 10 & 22 & 34 & 6 & 2 \\
\hline & $\%$ & 13.51 & 29.73 & 45.95 & 8.11 & 2.70 \\
\hline \multirow[t]{2}{*}{ NL } & Number & - & 3 & 10 & - & - \\
\hline & $\%$ & - & 23.08 & 76.92 & - & - \\
\hline \multirow[t]{2}{*}{ NO } & Number & - & 1 & 8 & 1 & - \\
\hline & $\%$ & - & 10.00 & 80.00 & 10.00 & - \\
\hline \multirow[t]{2}{*}{$\mathbf{P T}$} & Number & - & 1 & 13 & - & - \\
\hline & $\%$ & - & 7.14 & 92.86 & - & - \\
\hline \multirow[t]{3}{*}{ UK } & Number & 1 & 10 & 91 & 4 & 8 \\
\hline & $\%$ & 0.88 & 8.77 & 79.82 & 3.51 & 7.02 \\
\hline & Number & nrolled stud & nts 2003 & & & \\
\hline \multirow[t]{2}{*}{$\overline{\mathrm{CH}}$} & Number & "- & 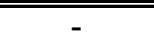 & $8 \overline{85,843}$ & 2,430 & 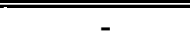 \\
\hline & $\%$ & - & - & 97.25 & 2.75 & - \\
\hline \multirow[t]{2}{*}{ DE } & Number & 59,777 & 790,247 & 489,403 & 1,888 & - \\
\hline & $\%$ & 4.46 & 58.92 & 36.49 & 0.14 & - \\
\hline \multirow[t]{2}{*}{ ES } & Number & 447,391 & 652,826 & 249,031 & - & - \\
\hline & $\%$ & 33.16 & 48.38 & 18.46 & - & - \\
\hline \multirow[t]{2}{*}{$\mathbf{F I}$} & Number & - & 31,304 & 110,300 & 4,869 & 612 \\
\hline & $\%$ & - & 21.28 & 74.99 & 3.31 & 0.42 \\
\hline \multirow[t]{2}{*}{ FR } & Number & - & 828,311 & 616,127 & - & - \\
\hline & $\%$ & - & 57.34 & 42.66 & - & - \\
\hline \multirow[t]{2}{*}{$\mathrm{HU}$} & Number & - & 145593 & 76,031 & - & - \\
\hline & $\%$ & - & 65.69 & 34.31 & - & - \\
\hline \multirow[t]{2}{*}{ IT } & Number & 737,120 & 659,767 & 365,224 & 5,617 & 567 \\
\hline & $\%$ & 41.69 & 37.31 & 20.65 & 0.32 & 0.03 \\
\hline \multirow[t]{2}{*}{ NL } & Number & - & 67,735 & 119,963 & - & - \\
\hline & $\%$ & - & 36.09 & 63.91 & - & - \\
\hline \multirow[t]{2}{*}{ NO } & Number & - & 30,056 & 70,421 & 1,986 & - \\
\hline & $\%$ & - & 29.33 & 68.73 & 1.94 & - \\
\hline \multirow[t]{2}{*}{ PT } & Number & - & 23,294 & 126,478 & - & - \\
\hline & $\%$ & - & 15.55 & 84.45 & - & - \\
\hline \multirow[t]{2}{*}{ UK } & Number & 141,635 & 226,264 & 997,312 & 5,109 & 1,630 \\
\hline & $\%$ & 10.32 & 16.49 & 72.69 & 0.37 & 0.12 \\
\hline
\end{tabular}

Very large: more than 50,000 undergraduate students enrolled

Large: from 20,000 to 50,000 undergraduate students enrolled

Medium: from 2,000 to 20,000 undergraduate students enrolled

Small: from 500 to 2,000 undergraduate students enrolled

Very small: less than 500 undergraduate students enrolled

Table A1 Distribution of universities by size (enrolled undergraduate students). Year 2003. 


\begin{tabular}{|c|c|c|c|c|c|c|}
\hline Country & & Very large & Large & Medium & Small & Very small \\
\hline & \multicolumn{6}{|c|}{ Number of universities } \\
\hline \multirow[t]{2}{*}{$\overline{\mathrm{CH}}$} & Number & 2 & 5 & 4 & 1 & 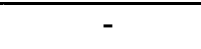 \\
\hline & $\%$ & 16.67 & 41.67 & 33.33 & 8.33 & - \\
\hline \multirow[t]{2}{*}{$\mathrm{DE}$} & Number & 10 & 31 & 31 & - & - \\
\hline & $\%$ & 13.89 & 43.06 & 43.06 & - & - \\
\hline \multirow[t]{2}{*}{ ES } & Number & 1 & 15 & 32 & - & - \\
\hline & $\%$ & 2.08 & 31.25 & 66.67 & - & - \\
\hline \multirow[t]{2}{*}{$\mathbf{F I}$} & Number & - & 1 & 14 & 4 & 1 \\
\hline & $\%$ & - & 5.00 & 70.00 & 20.00 & 5.00 \\
\hline \multirow[t]{2}{*}{ FR } & Number & - & - & 80 & 6 & 2 \\
\hline & $\%$ & - & - & 90.91 & 6.82 & 2.27 \\
\hline \multirow[t]{2}{*}{ HU } & Number & - & - & 16 & - & - \\
\hline & $\%$ & - & - & 100.00 & - & - \\
\hline \multirow[t]{2}{*}{ IT } & Number & 2 & 15 & 50 & 9 & 3 \\
\hline & $\%$ & 2.53 & 18.99 & 63.29 & 11.39 & 3.80 \\
\hline \multirow[t]{2}{*}{ NL } & Number & - & 4 & 9 & - & - \\
\hline & $\%$ & - & 30.77 & 69.23 & - & - \\
\hline \multirow[t]{2}{*}{ NO } & Number & - & 2 & 2 & - & - \\
\hline & $\%$ & - & 50.00 & 50.00 & - & - \\
\hline \multirow[t]{2}{*}{$\mathbf{P T}$} & Number & - & 1 & 12 & 1 & - \\
\hline & $\%$ & - & 7.14 & 85.71 & 7.14 & - \\
\hline \multirow[t]{3}{*}{ UK } & Number & - & 15 & 81 & 14 & 6 \\
\hline & $\%$ & - & 12.93 & 69.83 & 12.07 & 5.17 \\
\hline & Number & cademic sta & employe & & & \\
\hline \multirow[t]{2}{*}{$\overline{\overline{\mathrm{CH}}}$} & Number & 13,250 & 1717,234 & 4,367 & 177 & - \\
\hline & $\%$ & 37.83 & 49.20 & 12.47 & 0.51 & - \\
\hline \multirow[t]{2}{*}{$\mathrm{DE}$} & Number & 56,829 & 104,456 & 32,421 & - & - \\
\hline & $\%$ & 29.34 & 53.93 & 16.74 & - & - \\
\hline \multirow[t]{2}{*}{ ES } & Number & 5,961 & 44,478 & 37,440 & - & - \\
\hline & $\%$ & 6.78 & 50.61 & 42.60 & - & - \\
\hline \multirow[t]{2}{*}{$\mathbf{F I}$} & Number & - & 3,384 & 11,514 & 521 & 25 \\
\hline & $\%$ & - & 21.91 & 74.55 & 3.37 & 0.16 \\
\hline \multirow[t]{2}{*}{ FR } & Number & - & - & 46,175 & 816 & 95 \\
\hline & $\%$ & - & - & 98.07 & 1.73 & 0.20 \\
\hline \multirow[t]{2}{*}{ HU } & Number & - & - & 14,824 & - & - \\
\hline & $\%$ & - & - & 100.00 & - & - \\
\hline \multirow[t]{2}{*}{ IT } & Number & 11,553 & 45,562 & 44,677 & 951 & 54 \\
\hline & $\%$ & 11.24 & 44.32 & 43.46 & 0.93 & 0.05 \\
\hline \multirow[t]{2}{*}{$\mathrm{NL}$} & Number & - & 9,682 & 12,559 & - & - \\
\hline & $\%$ & - & 43.53 & 56.47 & - & - \\
\hline \multirow[t]{2}{*}{ NO } & Number & - & 5,323 & 2,706 & - & - \\
\hline & $\%$ & - & 66.30 & 33.70 & - & - \\
\hline \multirow[t]{2}{*}{$\mathbf{P T}$} & Number & - & 2,347 & 11,163 & 191 & - \\
\hline & $\%$ & - & 17.13 & 81.48 & 1.39 & - \\
\hline UK & Number & - & 42,832 & 62,878 & 1,709 & 137 \\
\hline & $\%$ & - & 39.82 & 58.46 & 1.59 & 0.13 \\
\hline
\end{tabular}

Very large: more than 5,000 people employed in academic staff

Large: from 2,000 to 5,000 people employed in academic staff

Medium: from 200 to 2,000 people employed in academic staff

Small: from 50 to 200 upeople employed in academic staff

Very small: less than 50 people employed in academic staff

Table A2 Distribution of universities by size (total academic staff). Year 2003. 


\begin{tabular}{|c|c|c|c|c|c|c|}
\hline Country & & Very large & Large & Medium & Small & Very small \\
\hline & \multicolumn{5}{|c|}{ Number of universities } & \\
\hline \multirow[t]{2}{*}{$\overline{\mathrm{CH}}$} & Generalist & 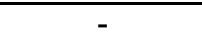 & 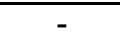 & 2 & 0 & 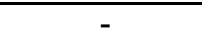 \\
\hline & Specialist & - & - & 8 & 2 & - \\
\hline \multirow[t]{2}{*}{ DE } & Generalist & 1 & 26 & 44 & 1 & - \\
\hline & Specialist & - & - & - & - & - \\
\hline \multirow[t]{2}{*}{ ES } & Generalist & 6 & 21 & 21 & - & - \\
\hline & Specialist & - & - & - & - & - \\
\hline \multirow[t]{2}{*}{$\mathbf{F I}$} & Generalist & - & 1 & 3 & 0 & 0 \\
\hline & Specialist & - & 0 & 11 & 3 & 2 \\
\hline \multirow[t]{2}{*}{ FR } & Generalist & - & 17 & 32 & - & - \\
\hline & Specialist & - & 16 & 23 & - & - \\
\hline \multirow[t]{2}{*}{$\mathrm{HU}$} & Generalist & - & 4 & 6 & - & - \\
\hline & Specialist & - & 1 & 3 & - & - \\
\hline \multirow[t]{2}{*}{ IT } & Generalist & 9 & 13 & 12 & 0 & 0 \\
\hline & Specialist & 1 & 9 & 22 & 6 & 2 \\
\hline \multirow[t]{2}{*}{ NL } & Generalist & - & 1 & 1 & - & - \\
\hline & Specialist & - & 2 & 9 & - & - \\
\hline \multirow[t]{2}{*}{ NO } & Generalist & - & 0 & 7 & 1 & - \\
\hline & Specialist & - & 1 & 1 & 0 & - \\
\hline \multirow[t]{2}{*}{$\mathbf{P T}$} & Generalist & - & 1 & 8 & - & - \\
\hline & Specialist & - & 0 & 5 & - & - \\
\hline \multirow[t]{3}{*}{ UK } & Generalist & 0 & 10 & 68 & 0 & 0 \\
\hline & Specialist & 1 & 0 & 23 & 4 & 5 \\
\hline & Percentag & & & & & \\
\hline \multirow[t]{2}{*}{$\overline{\overline{\mathbf{C H}}}$} & Generalist & - & - & 16.67 & 0 & - \\
\hline & Specialist & - & - & 66.67 & 16.67 & - \\
\hline \multirow[t]{2}{*}{ DE } & Generalist & 1.39 & 36.11 & 61.11 & 1.39 & - \\
\hline & Specialist & - & - & - & - & - \\
\hline \multirow[t]{2}{*}{ ES } & Generalist & 12.50 & 43.75 & 43.75 & - & - \\
\hline & Specialist & - & - & - & - & - \\
\hline \multirow[t]{2}{*}{$\mathbf{F I}$} & Generalist & - & 5.00 & 15.00 & 0.00 & 0.00 \\
\hline & Specialist & - & 0.00 & 55.00 & 15.00 & 10.00 \\
\hline \multirow[t]{2}{*}{ FR } & Generalist & - & 19.32 & 36.36 & - & - \\
\hline & Specialist & - & 18.18 & 26.14 & - & - \\
\hline \multirow[t]{2}{*}{ HU } & Generalist & - & 28.57 & 42.86 & - & - \\
\hline & Specialist & - & 7.14 & 21.43 & - & - \\
\hline \multirow[t]{2}{*}{ IT } & Generalist & 12.16 & 17.57 & 16.22 & - & - \\
\hline & Specialist & 1.35 & 12.16 & 29.73 & 8.11 & 2.70 \\
\hline \multirow[t]{2}{*}{$\mathrm{NL}$} & Generalist & - & 8 & 8 & - & - \\
\hline & Specialist & - & 15.38 & 69.23 & - & - \\
\hline \multirow[t]{2}{*}{ NO } & Generalist & - & 0.00 & 70.00 & 10.00 & - \\
\hline & Specialist & - & 10.00 & 10.00 & 0.00 & - \\
\hline \multirow[t]{2}{*}{ PT } & Generalist & - & 7 & 57 & - & - \\
\hline & Specialist & - & 0.00 & 35.71 & - & - \\
\hline UK & Generalist & 0 & 9.01 & 61.26 & 0 & 0 \\
\hline & Specialist & 0.90 & 0.00 & 20.72 & 3.60 & 4.50 \\
\hline
\end{tabular}

Very large: more than 50,000 undergraduate students enrolled

Large: from 20,000 to 50,000 undergraduate students enrolled

Medium: from 2,000 to 20,000 undergraduate students enrolled

Small: from 500 to 2,000 undergraduate students enrolled

Very small: less than 500 undergraduate students enrolled

Table A3 Generalist specialist by size (enrolled students 2003) 
Appendix B. Sources of data by category and structure of the Aquameth database

\begin{tabular}{|c|c|}
\hline \multicolumn{2}{|r|}{ GENERAL INFORMATION ON HEI } \\
\hline FINLAND & $\begin{array}{l}\text { http://fi.wikipedia.org/wiki/Yliopistot; } \\
\text { http://fi.wikipedia.org/wiki/NUTS:FI; http://kotaplus.csc.fi:7777 } \\
\text { KOTA-online }\end{array}$ \\
\hline FRANCE & $\begin{array}{l}\text { Ministry of Research and Education - Sous-direction des synthèses } \\
\text { statistiques, Direction de l'évaluation, de la prospective et de la } \\
\text { performance; http://www.reseau-chu.org }\end{array}$ \\
\hline GERMANY & $\begin{array}{l}\text { Federal Statistical Office of Germany: "Finanzstatistische } \\
\text { Kennzahlen für den Hochschulbereich auf Basis der } \\
\text { Hochschulfinanzstatistik"; institutions' web pages }\end{array}$ \\
\hline $\begin{array}{l}\text { HUNGARY } \\
\text { ITALY }\end{array}$ & $\begin{array}{l}\text { institutions’ web pages } \\
\text { institutions’ web pages }\end{array}$ \\
\hline $\begin{array}{l}\text { NETHERLAND } \\
\text { NORWAY } \\
\text { PORTUGAL }\end{array}$ & The World of Learning 43rd edition (Europa Publications Ltd 1992) \\
\hline SPAIN & $\begin{array}{l}\text { annual university statistics of the Council of University } \\
\text { Coordination (CCU) and from the annual publication of Higher } \\
\text { Education Statistics of the National Institute of Statistics (INE). }\end{array}$ \\
\hline SWITZERLAN & \\
\hline $\begin{array}{l}\text { UNITED } \\
\text { KINGDOM }\end{array}$ & institutions’ web pages \\
\hline
\end{tabular}




\section{REVENUES \& EXPENDITURES}

\begin{tabular}{|c|c|}
\hline FINLAND & http://kotaplus.csc.fi:7777 KOTA online \\
\hline FRANCE & --- \\
\hline GERMANY & $\begin{array}{l}\text { Federal Statistical Office of Germany: "Finanzstatistische } \\
\text { Kennzahlen für den Hochschulbereich auf Basis der } \\
\text { Hochschulfinanzstatistik" }\end{array}$ \\
\hline HUNGARY & $\begin{array}{l}\text { Hugarian Central Statistical Office (HSCO) database (special } \\
\text { permission) }\end{array}$ \\
\hline ITALY & $\begin{array}{l}\text { Up to } 1998 \text { CRUI (Conference of Rectors) annual enquiry. CNVSU } \\
\text { (National council for University system evaluation) annual enquiry } \\
\text { after } 1999\end{array}$ \\
\hline NETHERLAND & $\begin{array}{l}\text { Own institutional financial reports, Dutch Statistical Office (CBS), } \\
\text { Ministry of Education, Association of Universities (VSNU) }\end{array}$ \\
\hline NORWAY & Database for Statistics on Higher Education \\
\hline PORTUGAL & $\begin{array}{l}\text { Department of Fiscal Execution of the Portuguese Ministry of } \\
\text { Education }\end{array}$ \\
\hline SPAIN & $\begin{array}{l}\text { biannual publication of Spanish Universities' Figures from the Vice- } \\
\text { Chancellors Conference of the Spanish Universities (CRUE) }\end{array}$ \\
\hline SWITZERLAND & $\begin{array}{l}\text { Swiss University Information Database (Système d'Information } \\
\text { Universitaire Suisse - SIUS) }\end{array}$ \\
\hline $\begin{array}{l}\text { UNITED } \\
\text { KINGDOM }\end{array}$ & $\begin{array}{l}\text { www.hesa.ac.uk/products/pubs/home.htm (data about the university } \\
\text { system by institution for the period 1994/2003); www.data- } \\
\text { archive.ac.uk (data about the university system by institution for the } \\
\text { period 1984/1992. For the old universities only.) }\end{array}$ \\
\hline
\end{tabular}




\section{PERSONNEL}

\begin{tabular}{|c|c|}
\hline FINLAND & http://kotaplus.csc.fi:7777 KOTA-online \\
\hline FRANCE & $\begin{array}{l}\text { MENESR - DGRH } \\
\text { Service des personnels enseignants de l'enseignement supérieur et de } \\
\text { la recherche } \\
\text { Bureau des études de gestion prévisionnelle DGRH A1-1 } \\
\text { "Situation des personnels enseignants non permanents affectés dans } \\
\text { l'enseignement supérieur"; survey 2004, 2005, 2006, 2007 } \\
\text { 2004-05-06: MENESR, Direction des personnels enseignants - } \\
\text { Sous-direction des études et de la gestion prévisionnelle, Bureau de } \\
\text { la gestion prévisionnelle des enseignants du supérieur- DPE A6 -; } \\
\text { 2007: MENESR, Direction générale des ressources humaines - } \\
\text { Sous-direction des études de gestion prévisionnelle, statutaires et des } \\
\text { affaires communes Bureau des études de gestion prévisionnelle- } \\
\text { DGRH A1-1 - available at : } \\
\text { http://www.education.gouv.fr/personnel/enseignant_superieur/ensei } \\
\text { gnant_chercheur/statistiques.htm }\end{array}$ \\
\hline GERMANY & $\begin{array}{l}\text { Federal Statistical Office of Germany: "Personal an Hochschulen“; } \\
\text { Federal Statistical Office of Germany: "Finanzstatistische } \\
\text { Kennzahlen für den Hochschulbereich auf Basis der } \\
\text { Hochschulfinanzstatistik" }\end{array}$ \\
\hline HUNGARY & HSCO (special permission) \\
\hline ITALY & $\begin{array}{l}\text { CRUI (Conference of Rectors) annual enqiry for 1996. MUR } \\
\text { (Ministery of University and Research) dataset on academic } \\
\text { permanent staff and on contract positions from 1997; CNVSU 1997- } \\
2000\end{array}$ \\
\hline NETHERLAND & $\begin{array}{l}\text { Association of Dutch Universities (VSNU). It is included in the so- } \\
\text { called WOPI database }\end{array}$ \\
\hline NORWAY & NIFU STEP R\&D statistics \\
\hline PORTUGAL & Observatory on Science and Technology, from 1987 to 2002 \\
\hline SPAIN & $\begin{array}{l}\text { National Institute of Statistics annual publication of Higher } \\
\text { Education Statistics; Vice-Chancellors Conference of the Spanish } \\
\text { Universities publication of Spanish Universities’ Figures; Council } \\
\text { of University Coordination report of scientific personnel in } 1999\end{array}$ \\
\hline SWITZERLAND & $\begin{array}{l}\text { Swiss University Information Database (Système d'Information } \\
\text { Universitaire Suisse - SIUS) }\end{array}$ \\
\hline $\begin{array}{l}\text { UNITED } \\
\text { KINGDOM }\end{array}$ & $\begin{array}{l}\text { RAE data available from www.hefce.ac.uk/research/assessment/ } \\
\text { (1992 and } 1996 \text { exercises); Higher Education \& Research } \\
\text { Opportunities (HERO) website (2001 exercise) } \\
\text { www.hero.ac.uk/rae/index.htm }\end{array}$ \\
\hline
\end{tabular}




\section{EDUCATION PRODUCTION}

\begin{tabular}{|c|c|}
\hline FINLAND & http://kotaplus.csc.fi:7777 KOTA-online \\
\hline FRANCE & $\begin{array}{l}\text { Ministry of Research and Education (MENESR), Sous-direction des } \\
\text { synthèses statistiques } \\
\text { DEPP - Direction de l'évaluation, de la prospective et de la } \\
\text { performance }\end{array}$ \\
\hline GERMANY & $\begin{array}{l}\text { Federal Statistical Office of Germany: "Studierende an } \\
\text { Hochschulen"; "Finanzstatistische Kennzahlen für den } \\
\text { Hochschulbereich auf Basis der Hochschulfinanzstatistik" } \\
\text { "Prüfungen an Hochschulen" }\end{array}$ \\
\hline HUNGARY & Ministry Of Education (MoE) \\
\hline ITALY & $\begin{array}{l}\text { CRUI annual enqiry for 1996. MUR dataset on student population } \\
\text { from } 1997\end{array}$ \\
\hline NETHERLAND & $\begin{array}{l}\text { Ministry of Education's "Een Cijfer-HO" database; VSNU (WOPI } \\
\text { database); KUOZ database }\end{array}$ \\
\hline NORWAY & $\begin{array}{l}\text { Database for Statistics on Higher Education; Doctoral Degree } \\
\text { Register operated by NIFU STEP }\end{array}$ \\
\hline $\begin{array}{l}\text { PORTUGAL } \\
\text { SPAIN }\end{array}$ & $\begin{array}{l}\text { Portuguese Observatory on Science and Higher Education (OCES). } \\
\text { systematic publication of the Council of University Coordination } \\
\text { from the University Statistics }\end{array}$ \\
\hline SWITZERLAND & $\begin{array}{l}\text { Swiss University Information Database (Système d'Information } \\
\text { Universitaire Suisse - SIUS) }\end{array}$ \\
\hline $\begin{array}{l}\text { UNITED } \\
\text { KINGDOM }\end{array}$ & $\begin{array}{l}\text { RAE data available from www.hefce.ac.uk/research/assessment/ } \\
\text { (1992 and } 1996 \text { exercises); Higher Education \& Research } \\
\text { Opportunities (HERO) website (2001 exercise) } \\
\text { www.hero.ac.uk/rae/index.htm }\end{array}$ \\
\hline
\end{tabular}




\section{RESEARCH AND TECHNOLOGY PRODUCTION}

\begin{tabular}{|c|c|}
\hline FINLAND & $\begin{array}{l}\text { Thomson Scientific'c National Citation Report (NCR). Source: } \\
\text { Miettinen M. and J. Selovuori (2007) }\end{array}$ \\
\hline FRANCE & $\begin{array}{l}\text { Survey on TT activities of French Universities, 2006, BETA for } \\
\text { MENESR, CPU (Conference of University Rectors) }\end{array}$ \\
\hline GERMANY & $\begin{array}{l}\text { Federal Statistical Office of Germany: "Finanzstatistische } \\
\text { Kennzahlen für den Hochschulbereich auf Basis der } \\
\text { Hochschulfinanzstatistik" }\end{array}$ \\
\hline HUNGARY & $\begin{array}{l}\text { ISI Science Citation Index and Social Sciences Citation Index; } \\
\text { HSCO (special permission) }\end{array}$ \\
\hline ITALY & $\begin{array}{l}\text { ISI Science Citation Index and Social Sciences Citation Index; } \\
\text { CNVSU annual enquiry; special enquiries }\end{array}$ \\
\hline NETHERLAND & $\begin{array}{l}\text { From CWTS (specially derived from ISI Science Citation and Social } \\
\text { Science Citation Index); universities' websites; special study for the } \\
\text { Ministry of Economic Affairs ("Researchers op Ondernemerspad") } \\
\text { by TOP Spin Int'l; Bekkers et al. (Journal of Technology Transfer, } \\
\text { 2006, Vol 31) }\end{array}$ \\
\hline NORWAY & $\begin{array}{l}\text { ISI, National Citation Report (subset for Norway); R\&D Statistics } \\
\text { compiled by NIFU STEP cover only R\&D part of universities } \\
\text { activities }\end{array}$ \\
\hline PORTUGAL & $\begin{array}{l}\text { National Citation Report for Portugal 1981-2002 - Institute for } \\
\text { Scientific Information; Portuguese Scientific Production: } \\
\text { construction of Bibliometric indicators - OCES }\end{array}$ \\
\hline SPAIN & $\begin{array}{l}\text { Web of Science Database ( } 3 \text { of } 5 \text { databases: Science Citation Index } \\
\text { Expanded, Social Sciences Citation Index, Arts and Humanities } \\
\text { Citation Index); technology transfer office; biannual publication of } \\
\text { Spanish Universities' Figures CRUE }\end{array}$ \\
\hline SWITZERLAND & $\begin{array}{l}\text { Centre d'Etudes sur la Science et la Technologie (CEST). regularly } \\
\text { bibliometric indicators and analysis on Switzerland (including time } \\
\text { series for the period 1981-2001; CEST surveys on TT and } \\
\text { cooperation with private economy in HEI }\end{array}$ \\
\hline $\begin{array}{l}\text { UNITED } \\
\text { KINGDOM }\end{array}$ & $\begin{array}{l}\text { RAE data available from www.hefce.ac.uk/research/assessment/ } \\
\text { (1992 and } 1996 \text { exercises); Higher Education \& Research } \\
\text { Opportunities (HERO) website }\end{array}$ \\
\hline
\end{tabular}




\section{Appendix C. Aquameth database structure}

\begin{tabular}{|c|c|c|c|c|c|c|c|c|c|c|c|c|c|}
\hline Country & Code & University & $\begin{array}{c}\text { Variable } \\
\text { code }\end{array}$ & $\begin{array}{c}\text { Variabl } \\
\text { e } \\
\text { name }\end{array}$ & $\begin{array}{l}\mathbf{F} \\
\mathbf{I} \\
\mathbf{E} \\
\mathbf{L} \\
\mathbf{D}\end{array}$ & $\begin{array}{c}\text { Gende } \\
\mathbf{r}\end{array}$ & $\begin{array}{l}1 \\
9 \\
9 \\
4\end{array}$ & $\begin{array}{l}1 \\
9 \\
9 \\
5\end{array}$ & $\cdots$ & $\cdots$ & $\begin{array}{l}2 \\
0 \\
0 \\
6\end{array}$ & $\begin{array}{l}2 \\
0 \\
0 \\
7\end{array}$ & $\ldots$ \\
\hline Finland & FI001 & AcaArts & & & & & & & & & & & \\
\hline Finland & FI... & $\ldots$ & & & & & & & & & & & \\
\hline France & FR001 & & & & & & & & & & & & \\
\hline France & FR... & $\ldots$ & & & & & & & & & & & \\
\hline Germany & DE001 & Bauhaus U Weimar & & & & & & & & & & & \\
\hline Germany & DE... & $\ldots$ & & & & & & & & & & & \\
\hline Hungary & HU001 & $\ldots$ & & & & & & & & & & & \\
\hline Hungary & HU... & $\ldots$ & & & & & & & & & & & \\
\hline Italy & IT001 & Ancona & & & & & & & & & & & \\
\hline Italy & IT... & $\ldots$ & & & & & & & & & & & \\
\hline Netherlands & NL001 & $\begin{array}{l}\text { Erasmus } \\
\text { Universiteit } \\
\text { Rotterdam }\end{array}$ & & & & & & & & & & & \\
\hline Netherlands & NL... & $\ldots$ & & & & & & & & & & & \\
\hline Norway & NO001 & $\begin{array}{l}\text { Norges teknisk- } \\
\text { naturvitenskapelige }\end{array}$ & & & & & & & & & & & \\
\hline Norway & NO... & $\ldots$ & & & & & & & & & & & \\
\hline Portugal & РT001 & $\begin{array}{l}\text { Instituto Superior } \\
\text { de Ciências do } \\
\text { Trabalho e da } \\
\text { Empresa }\end{array}$ & & & & & & & & & & & \\
\hline Porugal & PT... & $\ldots$ & & & & & & & & & & & \\
\hline Spain & ES001 & A. Corunya & & & & & & & & & & & \\
\hline Spain & ES... & $\ldots$ & & & & & & & & & & & \\
\hline Switzerland & СH001 & Bern & & & & & & & & & & & \\
\hline Switzerland & CH... & & & & & & & & & & & & \\
\hline $\begin{array}{l}\text { United } \\
\text { Kingdom }\end{array}$ & UK001 & $\begin{array}{l}\text { Anglia Polytechnic } \\
\text { University }\end{array}$ & & & & & & & & & & & \\
\hline $\begin{array}{l}\text { United } \\
\text { Kingdom }\end{array}$ & UK... & $\ldots$ & & & & & & & & & & & \\
\hline
\end{tabular}

\section{Description of fields}

Country: name of the university's country. At present (July 2008) data regards 11 European countries: Finland, France, Germany, Hungary, Italy, The Netherlands, Norway, Portugal, Spain, Switzerland, United Kingdom

Code: identifies the single HEI in the database. First two letters refer to university's country; they are followed by a three digit numerical progressive code identifying HEI within its own country.

University: is the university name in domestic language. Sometimes is the university acronym

Variable code: is a two digit numerical code: first number refer to group of variable (five groups are identified in the database: revenues information, expenditures information, personnel information, education production information, research production information); the second is a progressive number identifying variable within its own group

Variable name: name of the variable collected

Area: when available data are split by area of research. Four broad areas of research have been identified according to Frascati Manual: Engineering and technology; medical sciences; natural sciences; social sciences and humanities (plus a residual multidisciplinary area for some countries which is marginal).

Gender: when possible variables are split by gender (male, female, total). 


\section{Appendix D. Definitions of funding}

\begin{tabular}{|c|c|c|c|c|c|c|}
\hline Country & $\begin{array}{l}\text { Tuition } \\
\text { and fees }\end{array}$ & $\begin{array}{l}\text { Governme } \\
\text { nt funding }\end{array}$ & $\begin{array}{c}\text { EU and } \\
\text { other } \\
\text { internation } \\
\text { al funding }\end{array}$ & $\begin{array}{l}\text { Private } \\
\text { funding }\end{array}$ & $\begin{array}{c}\text { Asset } \\
\text { revenue } \\
\text { s }\end{array}$ & Other funds \\
\hline $\mathbf{C H}$ & Fees & $\begin{array}{l}\text { General and } \\
\text { contracts funding } \\
\text { from central and } \\
\text { regional } \\
\text { Governments + } \\
\text { other prog (not } \\
\text { divided by } \\
\text { subcategories) }\end{array}$ & $\begin{array}{l}\text { EU and } \\
\text { international } \\
\text { funding }\end{array}$ & $\begin{array}{l}\text { General and } \\
\text { project } \\
\text { funding form } \\
\text { private sector } \\
\text { (profit and } \\
\text { non-profit) } \\
\text { plus services } \\
\text { revenues } \\
\text { (revenues } \\
\text { from } \\
\text { continuing } \\
\text { education and } \\
\text { service } \\
\text { activities) }\end{array}$ & $\begin{array}{l}\text { Patrimonial } \\
\text { funds }\end{array}$ & --- \\
\hline DE & $\begin{array}{l}\text { administrativ } \\
\text { e revenues: } \\
\text { revenue } \\
\text { which has } \\
\text { been earned } \\
\text { by the } \\
\text { university for } \\
\text { services } \\
\text { (without } \\
\text { research), } \\
\text { e.g. revenue } \\
\text { from medical } \\
\text { treatment, } \\
\text { selling } \\
\text { publications, } \\
\text { selling } \\
\text { agricultural } \\
\text { products, etc. }\end{array}$ & $\begin{array}{l}\text { Current income } \\
\text { from state budget }\end{array}$ & --- & --- & --- & --- \\
\hline ES & Student fees & $\begin{array}{l}\text { Funds provided } \\
\text { by central and } \\
\text { regional } \\
\text { Government plus } \\
\text { other public } \\
\text { institutions funds }\end{array}$ & EU funding & Private funds & $\begin{array}{l}\text { Patrimonial } \\
\text { funds }\end{array}$ & $\begin{array}{l}\text { other funds (financial assests } \\
+ \text { financial liabilities + real } \\
\text { investments) }\end{array}$ \\
\hline FI & $\begin{array}{l}\text { Not relevant. } \\
\text { In the } \\
\text { Netherlands } \\
\text { there are no } \\
\text { tuition or } \\
\text { fees for } \\
\text { students in } \\
\text { public higher } \\
\text { education } \\
\text { institutions }\end{array}$ & & EU funding & $\begin{array}{l}\text { Funding from } \\
\text { domestic and } \\
\text { international } \\
\text { private firms } \\
\text { and non } \\
\text { government } \\
\text { agencies }\end{array}$ & --- & --- \\
\hline FR & --- & --- & --- & $\begin{array}{l}\text { Only project- } \\
\text { based funding } \\
\text { and services } \\
\text { activities }\end{array}$ & --- & --- \\
\hline
\end{tabular}

Table D1 Definitions of funding by country. 


\begin{tabular}{|c|c|c|c|c|c|c|}
\hline Country & $\begin{array}{l}\text { Tuition } \\
\text { and fees }\end{array}$ & $\begin{array}{l}\text { Governme } \\
\text { nt funding }\end{array}$ & $\begin{array}{l}\text { EU and } \\
\text { other } \\
\text { internation } \\
\text { al funding }\end{array}$ & $\begin{array}{l}\text { Private } \\
\text { funding }\end{array}$ & $\begin{array}{l}\text { Asset } \\
\text { revenues }\end{array}$ & Other funds \\
\hline HU & $\begin{array}{l}\text { Not relevant } \\
\text { because only } \\
\text { a small part } \\
\text { of students } \\
\text { has to pay } \\
\text { tution fees. } \\
\text { The data is } \\
\text { not available. }\end{array}$ & $\begin{array}{l}\text { General and } \\
\text { contracts funding } \\
\text { from Government }\end{array}$ & $\begin{array}{l}\text { EU and } \\
\text { international } \\
\text { funding (grants } \\
\text { and contracts) }\end{array}$ & $\begin{array}{l}\text { General and } \\
\text { project } \\
\text { funding form } \\
\text { private sector }\end{array}$ & --- & Other revenues \\
\hline IT & $\begin{array}{l}\text { Tuition and } \\
\text { fees }\end{array}$ & $\begin{array}{l}\text { Funds provided } \\
\text { by the national } \\
\text { Government and } \\
\text { other public } \\
\text { institutions . In } \\
1999 \text { and } 2000 \\
\text { includes only } \\
\text { funds from } \\
\text { Ministery of } \\
\text { University and } \\
\text { Research (in } 1999 \\
\text { only ordinary } \\
\text { transfers -FFO) }\end{array}$ & $\begin{array}{l}\text { EU and } \\
\text { international } \\
\text { funding. Up to } \\
1998 \text { only EU } \\
\text { funding }\end{array}$ & $\begin{array}{l}\text { Current and } \\
\text { capital funds } \\
\text { from business } \\
\text { sector and } \\
\text { from } \\
\text { organization } \\
\text { other than } \\
\text { public } \\
\text { insitutions. } \\
\text { Up to } 1998 \\
\text { data refers } \\
\text { only to } \\
\text { private sector; } \\
\text { In year 2000 } \\
\text { it includes all } \\
\text { funds } \\
\text { received from } \\
\text { organizations } \\
\text { other than } \\
\text { Ministery of } \\
\text { University } \\
\text { and Research. }\end{array}$ & $\begin{array}{l}\text { Income from } \\
\text { the investment } \\
\text { of general } \\
\text { endowments } \\
\text { (including } \\
\text { interest or } \\
\text { dividends, bank } \\
\text { interest or rents } \\
\text { from real } \\
\text { property) + } \\
\text { patrimonial } \\
\text { alienations + } \\
\text { borrowing. }\end{array}$ & $\begin{array}{l}\text { Other revenues. } 2000 \\
\text { figure refers to borrowing } \\
\text { funds. }\end{array}$ \\
\hline NL & $\begin{array}{l}\text { Tuition and } \\
\text { fees }\end{array}$ & $\begin{array}{l}\text { General and } \\
\text { contracts funding } \\
\text { from Government }\end{array}$ & $\begin{array}{l}\text { All international } \\
\text { grants (may even } \\
\text { formally be grants } \\
\text { from private } \\
\text { foundations from } \\
\text { abroad) }\end{array}$ & $\begin{array}{l}\text { General and } \\
\text { project } \\
\text { funding form } \\
\text { private sector } \\
\text { (profit and } \\
\text { non-profit) }\end{array}$ & --- & $\begin{array}{l}\text { Income from interest and } \\
\text { from sales \& services } \\
\text { (excluding contract income } \\
\text { and fees) }\end{array}$ \\
\hline NO & $\begin{array}{l}\text { Not relevant. } \\
\text { In Norway } \\
\text { there are no } \\
\text { tuition or } \\
\text { fees for } \\
\text { students in } \\
\text { public higher } \\
\text { education } \\
\text { institutions }\end{array}$ & $\begin{array}{l}\text { General and } \\
\text { contracts funding } \\
\text { from central } \\
\text { Government plus } \\
\text { contracts funding } \\
\text { from regional } \\
\text { Government. For } \\
\text { years } 1995 \text { to } \\
1997 \text { includes all } \\
\text { contract funding } \\
\text { and also funding } \\
\text { from the Research } \\
\text { Council of } \\
\text { Norway }\end{array}$ & $\begin{array}{l}\text { EU and } \\
\text { international } \\
\text { funding }\end{array}$ & $\begin{array}{l}\text { Funding from } \\
\text { private sector }\end{array}$ & --- & Other revenues \\
\hline PT & $\begin{array}{l}\text { Tuition Fees } \\
\text { - Student } \\
\text { Fees (UG) }\end{array}$ & $\begin{array}{l}\text { Government } \\
\text { Funding - } \\
\text { Formula (mostly } \\
\text { enrolments by } \\
\text { groups of } \\
\text { disciplines) }\end{array}$ & $\begin{array}{l}\text { EU and } \\
\text { International } \\
\text { Funding }\end{array}$ & $\begin{array}{l}\text { Private } \\
\text { Funding - } \\
\text { Postgraduate } \\
\text { Fees; Net } \\
\text { balances from } \\
\text { previous } \\
\text { years; } \\
\text { Contracts } \\
\text { with public } \\
\text { and private } \\
\text { institutions }\end{array}$ & & Other revenues not relevant \\
\hline
\end{tabular}

Table D1 (cont.) Definitions of funding by country. 


\begin{tabular}{|c|c|c|c|c|c|c|}
\hline Country & $\begin{array}{l}\text { Tuition } \\
\text { and fees }\end{array}$ & $\begin{array}{l}\text { Governme } \\
\text { nt funding }\end{array}$ & $\begin{array}{l}\text { EU and } \\
\text { other } \\
\text { internation } \\
\text { al funding }\end{array}$ & $\begin{array}{l}\text { Private } \\
\text { funding }\end{array}$ & $\begin{array}{l}\text { Asset } \\
\text { revenue } \\
\text { s }\end{array}$ & Other funds \\
\hline UK & $\begin{array}{l}\text { Students } \\
\text { fees: Total } \\
\text { income from } \\
\text { the } \\
\text { educational } \\
\text { activities } \\
\text { only }\end{array}$ & $\begin{array}{l}\text { Total funding } \\
\text { from general } \\
\text { budget and } \\
\text { central } \\
\text { government: } \\
\text { Total income } \\
\text { from the Higher } \\
\text { Education } \\
\text { Funding Councils } \\
\text { only } \\
\text { Total funding } \\
\text { from research } \\
\text { contracts and } \\
\text { central } \\
\text { government: } \\
\text { Total income } \\
\text { from the Office of } \\
\text { Science and } \\
\text { Technology } \\
\text { (Research } \\
\text { Councils) and } \\
\text { other UK } \\
\text { Government }\end{array}$ & $\begin{array}{l}\text { This variable } \\
\text { includes all } \\
\text { income in respect } \\
\text { of externally } \\
\text { sponsored } \\
\text { research carried } \\
\text { out by the } \\
\text { institution and } \\
\text { funded by the EU } \\
\text { plus overseas } \\
\text { institutions. }\end{array}$ & $\begin{array}{l}\text { This variable } \\
\text { includes all } \\
\text { income in } \\
\text { respect of } \\
\text { externally } \\
\text { sponsored } \\
\text { research } \\
\text { carried out by } \\
\text { the institution } \\
\text { and funded by } \\
\text { UK Industry } \\
\text { and/or UK } \\
\text { Charities }\end{array}$ & $\begin{array}{l}\text { This variable } \\
\text { includes the } \\
\text { full amount } \\
\text { of the } \\
\text { income from } \\
\text { the } \\
\text { investment } \\
\text { of general } \\
\text { endowments. } \\
\text { This includes } \\
\text { the income } \\
\text { earned from } \\
\text { the capital of } \\
\text { the } \\
\text { endowment } \\
\text { whether } \\
\text { arising from } \\
\text { the interest } \\
\text { or dividends } \\
\text { on } \\
\text { investments, } \\
\text { bank interest } \\
\text { or rents from } \\
\text { real property. }\end{array}$ & $\begin{array}{l}\text { This variable includes all } \\
\text { income in respect of services } \\
\text { rendered to outside bodies, } \\
\text { including the supply of goods } \\
\text { and consultancies, all non- } \\
\text { research income from UK } \\
\text { central government bodies, } \\
\text { non-departmental public } \\
\text { bodies, UK local authorities } \\
\text { and UK health and hospital } \\
\text { authorities, all non-research } \\
\text { income for services rendered } \\
\text { to industrial and commercial } \\
\text { companies and public } \\
\text { corporations operating in the } \\
\text { UK; income received from } \\
\text { UK health or hospital } \\
\text { authorities for the funding of } \\
\text { any employees of the } \\
\text { institution, including posts in } \\
\text { academic teaching, except } \\
\text { those relating to the provision } \\
\text { of a service and income from } \\
\text { property rights and licenses. } \\
\text { PLUS other funding from } \\
\text { assets }\end{array}$ \\
\hline
\end{tabular}

Table D1 (cont.) Definitions of funding by country. 